

\section{DISCLAIMER}

This report was prepared as an account of work sponsored by an agency of the United States Government. Neither the United States Government nor any agency Thereof, nor any of their employees, makes any warranty, express or implied, or assumes any legal liability or responsibility for the accuracy, completeness, or usefulness of any information, apparatus, product, or process disclosed, or represents that its use would not infringe privately owned rights. Reference herein to any specific commercial product, process, or service by trade name, trademark, manufacturer, or otherwise does not necessarily constitute or imply its endorsement, recommendation, or favoring by the United States Government or any agency thereof. The views and opinions of authors expressed herein do not necessarily state or reflect those of the United States Government or any agency thereof. 


\section{DISCLAIMER}

Portions of this document may be illegible in electronic image products. Images are produced from the best available original document. 


\section{LEG A L NOTICE}

This report was prepared as an account of Government sponsored work. Neither the United States, nor the Atomic Energy Commission, nor any person acting on behalf of the Commission:

A. Makes any warranty or representation, expressed or implied, with respect to the accuracy, completeness, or usefulness of the information contained in this report, or that the use of any information, apparatus, method, or process disclosed in this report may not infringe privately owned rights; or

B. Assumes any liabilities with respect to the use of, or for damages resulting from the use of any information, apparatus, method, or process disclosed in this report.

As used in the above, "person acting on behalf of the Commission" includes any employee or contractor of the Commission, or employee of such contractor, to the extent that such employee or contractor of the Commission, or employee of such contractor prepares, disseminates, or provides access to, any information pursuant to his employment or contract with the Commission, or his employment with such contractor.

Printed in the United States of America

Available from

Clearinghouse for Federal Scientific and Technical Information

National Bureau of Standards, U. S. Department of Commerce

Springfield, Virginia 22151

Price: Printed Copy $\$ 3.00$; Microfiche $\$ 0.65$ 


\title{
EFFECT OF MACHINING VARIABLES ON TOOL TEMPERATURES
}

\author{
Clarence A. Pippin
}

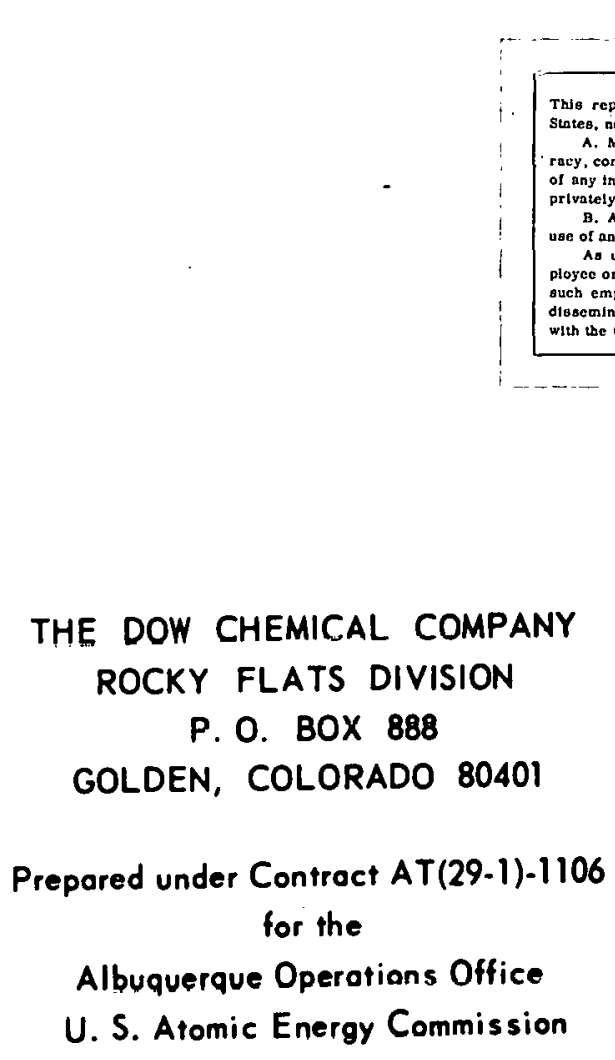

DISTRUBUTION OF THIS DOCUMENT IS LNLIMITF 
RFP-1409 


\section{CONTENTS}

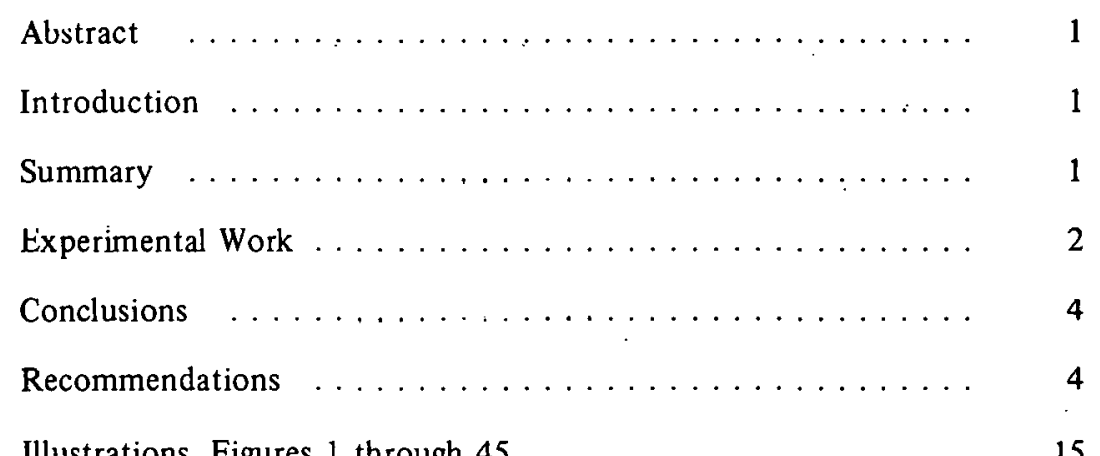


RFP-1409 


\title{
EFFECT OF MACHINING VARIABLES ON TOOL TEMPERATURES
}

\author{
Clarence A. Pippin
}

\begin{abstract}
The effect of machining variables on tool temperatures was studied in order to obtain the temperaturedistribution patterns at the tool tip. Four distances (depths) below the top surface of the tool bit were investigated, and results have been tabulated.
\end{abstract}

The depths of cut were varied between 0.005 and 0.040 inches and the feed rates ranged from 0.0021 to 0.0167 inches per revolution. The cutting speed was maintained at approximately 400 feet per minute.

Surface temperatures were determined by extrapolation from the four depths experimentally investigated. The maximum tool-surface temperature was $614^{\circ} \mathrm{F}$, at a 0.040 -inch depth of cut and a feed of 0.0167 inches per revolution,

The experimental work was done on Type-6061T6 aluminum which was easy to use. It is expected that such work will be useful to Rocky Flats as soon as random determinations can be made on plutonium.

\section{INTRODUCTION}

A large amount of tool-temperature data has been accumulated by various investigators. Unfortunately, none of the investigators report an outstanding method of getting such information and the best method known is extremely laborious. Metal buildup on the cutting tool has been troublesome, and the surface temperature of the tool will probably determine the extent of the metal buildup. There may also be a correlation between tool temperature and the inaximum instantaneous temperature attained by the workpiece. Such conditions are important when the material being machined has one or more phase transformation points occurring at moderately low temperatures.

\section{SUMMARY}

Four depths of thermocouple placement were used for the seven positions investigated in the nose of the throwaway type tool, ${ }^{1}$ Kendex SPG 433K6 (see Figure 1). ${ }^{2}$ The nose radius for these tools was 0.045 inches. The hole size used for thermocouple placement (Figure 2)

\footnotetext{
${ }^{1}$ Kennametal, Incorporated; I,atrobo, Pennsylvania.

${ }^{2}$ Figures are included at end of text.
}

was 0.020 inches in diameter. When drilling holes in carbide tool bits by means of EDM (electrical discharge machining), it is difficult to get the holes in the exact location desired. By means of X-ray and of physical measurements, the locations of these positions were determined and are listed in Table I. All four holes of any particular position will not be identical, although an attempt was made to achieve such results. The average was used as noted in Table 1.

Table II lists the surface temperatures as determined by extrapolation. The process of extrapolation always allows a chance for error, but the writer considers the reported data are reasonably reliable. The distance through which the extrapolation extends is not large. Any attompt to obtain the tool-surface temperature by direct measurement will probably involve friction as the chip moves over the tool. This factor might cause an appreciable error in any thermocouple reading.

As near as possible, the surface cutting speed was held at 400 feet per minute. In some cases, determinations were made above 400 feet per minute and then below 400 . The temperature for $\mathbf{4 0 0}$ feet per minute was determined by interpolation. Fortunately, the correction for cutting speed was usually small.

Figure 3 through Figure 17 show enlarged sketches of the tool insert. The shaded portion of each sketch shows the amount of metal being removed. In order to define the scale on these figures, a distance of 0.010 inches is shown. The line, which bisects the angle between the left edge and the right edge, is perpenidicular to the axis of the lathe when the tool is used. This is apparent, of course, from the depth of cut and feed as they are labeled on the figures. The surface-temperature distribution is as shown for each respective depth of cut and feed. In general, the surface temperature of the tool remains approximately the same if one doubles the depth of cut and reduces the feed to onc half of its former value.

Figure 18 through Figure 45 are plots of the temperature versus distance from the surface for seven positions and for cut depths of $0.005,0.010,0.020$, and 0.040 inches. Several factors contribute to the unpredictable temperature distributions shown here. Heat input to the tool comes from friction between the chip and tool, and from friction between the workpiece and the tool. Also the contact point between the chip and the tool does not 
TABLE I. Location of Data Points within Tool.

\begin{tabular}{|c|c|c|c|c|}
\hline Position & $\begin{array}{l}\text { Distance } \\
\text { from } \\
\text { Left Edge } \\
\text { (inches) }\end{array}$ & & $\begin{array}{c}\text { Distance } \\
\text { from } \\
\text { Right Edge } \\
\text { (inches) }\end{array}$ & $\begin{array}{c}\text { Distance } \\
\text { from } \\
\text { Top Surface } \\
\text { (inches) }\end{array}$ \\
\hline $1 \mathrm{~A}$ & 0.031 & & 0.031 & 0.071 \\
\hline $1 \mathrm{~B}$ & 0.031 & & 0.031 & 0.044 \\
\hline $1 \mathrm{C}$ & 0.031 & & 0.031 & 0.031 \\
\hline $1 \mathrm{D}$ & 0.031 & & 0.031 & 0.019 \\
\hline $\mathbf{3 A}$ & 0.062 & & 0.046 & 0.070 \\
\hline 3B & 0.062 & & 0.046 & 0.037 \\
\hline $3 \mathrm{C}$ & 0.062 & & 0.046 & 0.021 \\
\hline $3 D$ & 0.062 & . & 0.046 & 0.012 \\
\hline $4 A$ & 0.094 & & 0.092 & 0.067 \\
\hline IB & 0,094 & & 0.092 & 0.043 \\
\hline AC & 0.094 & & 0.09'2 & 0.0211 \\
\hline 4D & 0.094 & & 0.092 & 0.012 \\
\hline $5 \mathrm{~A}$ & 0.072 & & 0.028 & 0.060 \\
\hline 5B & 0.072 & & 0.028 & 0.038 \\
\hline sc & 0.072 & & 0.028 & 0.010 \\
\hline 5D & 0.072 & & 0.028 & 0.006 \\
\hline $6 \mathrm{~A}$ & 0.020 & & 0.075 & 0.078 \\
\hline $6 B$ & 0.020 & & 0.075 & 0.045 \\
\hline $6 \mathrm{C}$ & 0.020 & & 0.075 & 0.020 \\
\hline $6 \mathrm{D}$ & 0.020 & & 0.075 & 0.009 \\
\hline $7 \mathrm{~A}$ & 0.105 & & 0.028 & 0.067 \\
\hline $7 B$ & 0.105 & & n.028 & 0.036 \\
\hline 7C & 0.105 & & 0.028 & 0.017 \\
\hline 7D & 0.105 & & 0.028 & 0.006 \\
\hline $8 \mathrm{~A}$ & 0.019 & & 0.103 & 0.066 \\
\hline 8D & U.114 & & 0.103 & 0.034 \\
\hline $8 C$ & 0.019 & & 0.103 & 0.021 \\
\hline OD & nฺ 19 & & 0.103 & 0.001 \\
\hline
\end{tabular}

remain fixed even when the depth of cut and the feed are held constant. Frequently the tool, a short distance in from the surface, tends to be slightly warmer than un the surface. Some heat is lost from the surface by convection and radiation. However, when the chip is rubbing directly over a position, the temperature rises rapidly as the pnint being determined approaches the surface.

\section{EXPERIMENTAL WORK}

Several methods have been used in determining the tool temperature. ${ }^{3}$ Since a large amount of energy is utilized

\footnotetext{
${ }^{3}$ Erich Bickel. The Temperature on a Turning Tool. Swiss Federal Technical University, Zurich, Switzerland. Proceedings of the International Production Engineering Research Conference, Carnegie Institute of Technology, Pittsburg, Pennsylvania. September 9-12, 1963. Pages 89-94.
}

in extremely small areas during experiments, there will be large temperature gradients. To utilize the cutting tool as one part of a thermocouple would give what might be laheled as an average temperature. Such information was considered of little value. However, if a thermocouple were inserted into the tool, an accurate temperature reading could be obtained. Unfortunately, in order to avoid the changing of the tool-temperature profile, only one thermocouple hole can be tolerated. This means that it takes a long time to complete a tool-temperature study.

In order to facilitate obtaining of the data, the Kendex Type-SPG433K 6 throw-away inserts were used in an insert holder, Type SP42KSDN 65C. This holder was modified so that a Baldwin Lima Hamilton ${ }^{4}$ high temperature microminiature thermocouple, Type TCRC-ES-50, was held in place by moune of a spring (Figure 1). Thus, the exposed junction of the one-Inil ( 0.001 inches) thermociouple must be held tightly against the surface in order to obtain surface temperature. The thermocouple is tirst of all installed inside a holder as shown in Figure 2. This holder is inserted in the outer protective shield and held in place by the previously mentioned spring. The hole in the tool into which the thermocouple is inserted has been identified (arrow) in Figure 2.

It was necessary to first decide on the placement of the thermocouple, including its depth below the surface of the tool. Eight positions (1 through 8) were decided upon and four dupthe (A, $B, S_{1}$ and $\left.D\right)$ at each position. The positions actually obtained in the tools were not precisely thosc requested by the author. However, the final positions were clnse enough for use in expcrimental work and are listed in Table 1. These posiliuns wcrc determined by $\mathrm{X}$-ray and by physical nieasurcmonte: The luiles were drilled in the tool inserts by means of electric discharge machining (EDM). The hole diameter was U.U2U inches.

Pnsition 2 was abandnned because its position, as actually determined, essentially overlapped Position 1 . The nuse radius on these tools was 0.045 inches. Due to the configuration of the tool holder, the tool had a positive back rack of 6 degretes. The clcarance angle hetween the front of the tonl and the workpiere was 5 degrees.

The readout for the tool thermocouple consisted of a Beckman Fitgo Amplifier Model C-24, a Beckman Eput and Timer Model-6144 with a plug-in Voltage-to-Frequency Converter Unit, and a Beckman Model-1453 Printer. ${ }^{5}$ An ice bath was used as the reference cold junction. The

\footnotetext{
${ }^{4}$ Baldwin Lima Hamilton, B. L. H. Electronics, Waltham, Massachusetts.

${ }^{5}$ Beckman Instruments, Richmond, California.
} 
RFP-1409

TABLE II. Tabulated Tool Surface Temperatures.

\begin{tabular}{|c|c|c|c|c|c|}
\hline \multirow[b]{3}{*}{ Position } & \multirow{3}{*}{$\begin{array}{c}\text { Depth } \\
\text { of Cut } \\
\text { (inches) }\end{array}$} & \multicolumn{4}{|c|}{ (inches per revolution) } \\
\hline & & \multirow[t]{2}{*}{0.0021} & 0.0042 & \multirow{2}{*}{ heit Degrees $\frac{0.0083}{2}$} & \multirow[t]{2}{*}{0.0167} \\
\hline & & & & & \\
\hline 1 & 0.005 & 163 & 174 & 200 & - \\
\hline 1 & 0.010 & 169 & 222 & 312 & 420 \\
\hline 1 & 0.020 & 166 & 212 & 326 & 510 \\
\hline 1 & 0.040 & 260 & 311 & 401 & 610 \\
\hline 3 & 0.005 & 142 & 181 & 232 & - \\
\hline 3 & 0.010 & 170 & 212 & 273 & 355 \\
\hline 3 & 0.020 & 182 & 260 & 392 & 452 \\
\hline 3 & 0.040 & 253 & 425 & 510 & 523 \\
\hline 4 & 0.005 & 129 & 143 & 167 & - \\
\hline 4 & 0.010 & i51 & 168 & 202 & 249 \\
\hline 4. & 0.020 & 170 & 192 & 243 & 344 \\
\hline 4 & 0.040 & 203 & 237 & 305 & 445 \\
\hline . & & & & & \\
\hline 5 & 0.005 & 136 & 156 & 211 & - \\
\hline 5 & 0.010 & 159 & 188 & 344 & 344 \\
\hline 5 & 0.020 & 207 & 237 & 300 & 414 \\
\hline 5 & 0.040 & 266 & 311 & 412 & 551. \\
\hline 6 & 0.005 & 146 & 161 & 188 & - \\
\hline 6 & 0.010 & 162 & 188 & 240 & 334 \\
\hline 6 & 0.020 & 204 & 251 & 338 & 464 \\
\hline 6 & 0.040 & 247 & 325 & 459 & 614 \\
\hline 7 & 0.005 & 139 & 158 & 191 & - \\
\hline 7 & 0.010 & 158 & 176 & 210 & 249 \\
\hline 7 & 0.020 & 184 & 216. & 274 & 355 \\
\hline 7 & 0.040 & 219 & $267^{\circ}$ & 350 & 460 \\
\hline 8 & 0.005 & 130 & 152 & 187 & - \\
\hline 8 & 0.010 & 152 & 184 & 241 & 280 \\
\hline 8 & 0.020 & 191 & 231 & 301 & 357 \\
\hline 8 & 0.040 & 232 & 290 & 392 & 486 \\
\hline
\end{tabular}

accuracy of this readout system is far better than that required and more convenient.

The workpiece in every case was a cylindrical piece of Type $-6061 \mathrm{~T}-6$ aluminum which was 412 inches in diameter and 12 inches long, wliell machining began. Certain of the workpieces had a Baldwin Lima Hamilton high temperature microminiature thermocouple, Type TCRC-ES-50, embedded in them. The centerline of this thermocouple was parallel to the outer surface of the workpiece and 0.020 inches in from the surface. As the tool is cutting, the thermocouple is repeatedly cut off. It was expected that an intrinsic thermocouple would be formed between the two thermocouple wires and either the aluminum or the tool. All work involving the cutting of this thermocouple was done using a depth of cut of 0.040 inches which places the thermocouple at the center of the cut.

The workpieces in which the thermocouple was embedded had to be modified. Tlie lailstock end of the workpiece was turned to accept the slip-ring assembly. In addition, a 1 -inch axial hole and a $5 / 16$-inch radial hole were required in order to allow the thermocouple to be connected to the slip-ring assembly.

It is not obvious whether a thermocouple being cut off will give the peak temperature, the temperature on the surface of the tool, or some temperature in between. At least, the peak temperature would be given. There is a question as to whether friction changes the reading of a 
thermocouple. Although such information would be of value, more reliance was placed on the readings obtained from the tool thermocouple.

The major problem in making the measurement of the embedded thermocouple is in the recording of the signal. The cutoffs occurred about 0.167 seconds apart and the action took place in about 0.2 milliseconds. If the thermocouple remains open after it is cut, then there will be a large pickup of 60-hertz noise which will blot out all the previous valid temperature measurements. Readout attempts were made on an oscilloscope and also on a - Visicorder (oscillograph) ${ }^{6}$ with a Model M- 8000 galvanomoter ${ }^{7}$ which has a flat. response to 4800 hertz. The best appearing data seemed to be on the Visicorder, but still some doubt remained as to its accuracy. A galvanometer can indicate either too large or too small a value. More details on other attempts to get good data from a thermocouple being cut by the tool are given later in the ieport.

Now returning to the vast majority of the work involving only the tool temperature, the depths of cut were chosen as $0.005,0.010,0.020$, and 0.040 inches. The feed rates were $0.0021,0.0042,0.0083$, and 0.0167 inches per revolution. A feed rate of 0.0167 inches per revolution was not used with a depth of cut of 0.005 inches. In order to keep the number of variables down, the temperature of the workpiece was maintained between $86^{\circ}$ and $87^{\circ} \mathrm{F}$ at the start of each run. The surface feet per minute (sfm) were held near to 400 . This was difficult because the rotational speed of the lathe could not be changed by small amounts. Fortunately, this factor did not appear to be critical. Complete details are given on tabulated temperature data in Table III for all pusitions. Position 2 data are not given as noted earlier.

An example of the tool nomenclature used is as follows:

1. The four tepths of thermocouple placement for Position 1 was labeled as 1A, 1B, 1C, and 1D.

2. The intended depths below the top of the tool surface (although not the same as the actual depths) were 0.072 inches for $\mathrm{A}, 0.036$ inches for $\mathrm{B}, 0.018$ inches for $C$, and 0.009 inches for $D$.

3. For any given position, the $D$ depth was always used first and then C, B, and A used in that order. This study was started with $1 \mathrm{D}$ and progressed to $8 \mathrm{~A}$. However, certain runs had to be repeated to obtain better data.

\footnotetext{
${ }_{7}^{6}$ Minneapolis-Honeywell, Incorporated, Denver, Colorado.

${ }^{7}$ Ibiul.
}

In the Environmental Testing and Development Laboratory, a portable Ampex ${ }^{8}$ magnetic tape system with FM capability was available. Thus, three more runs were made in attempts to get better temperature information from a thermocouple embedded in the workpiece. All three runs were made with a depth of cut of 0.040 inches, but with feeds of $0.0042,0.0083$, and 0.0167 inches per revolution. Data were recorded at 60 inches per second tape speed and reproduced at 15 inches per second. This allowed an extension of the time base by a factor of 4 . Once the data are on magnetic tape, one can use various types of equipment to read the data in an accurate manner. The data on the third run (feed rate was 0.0167 inches per revolution) were inaccurate because of an error in the operation of the tape recouder.

\section{CONCI.USIONS}

1. The maximum tool surface temperature noted for the maximum depth of cut and feed rate was $614^{\circ} \mathrm{F}$.

2. The maximum workpiece temperature noted at the. point where the metal was heavily worked reached $1100^{\circ} \mathrm{F}$. This was at a feed rate of 0.0083 inches per revolution, but the tcmperature reached at a feed rate of 0.0167 inches would probably be higher.

3. The provioue conclusinn assumes that temperature rcadings are valid in spite of rubbing friction contact on the thermocouple junction. Such a condition may cause erronenus readings.

4. The effect of a change in cutting speed upon the tool temperature was much less than that obtained by a change in depth of cut or in the feed rate.

5 . In general, the surface temperaluic of the tool romains the same it the depth of cul is duubled, and simulta. neously the feed is reduced to one half its former value.

\section{RECOMMENDATIONS}

It is suggested that applications of this study be extended to plutonium. The general shapes of the temperature curves for plutonium are expected to be similar to those for aluminum. However, the curves would be shifted and random determination of the tool temperature during plutonium machining should allow such shifts to be made.

\footnotetext{
${ }^{8}$ Ampex Data Products, Redwood City, California.
} 
TABLE III: Tabulated Temperature Data.

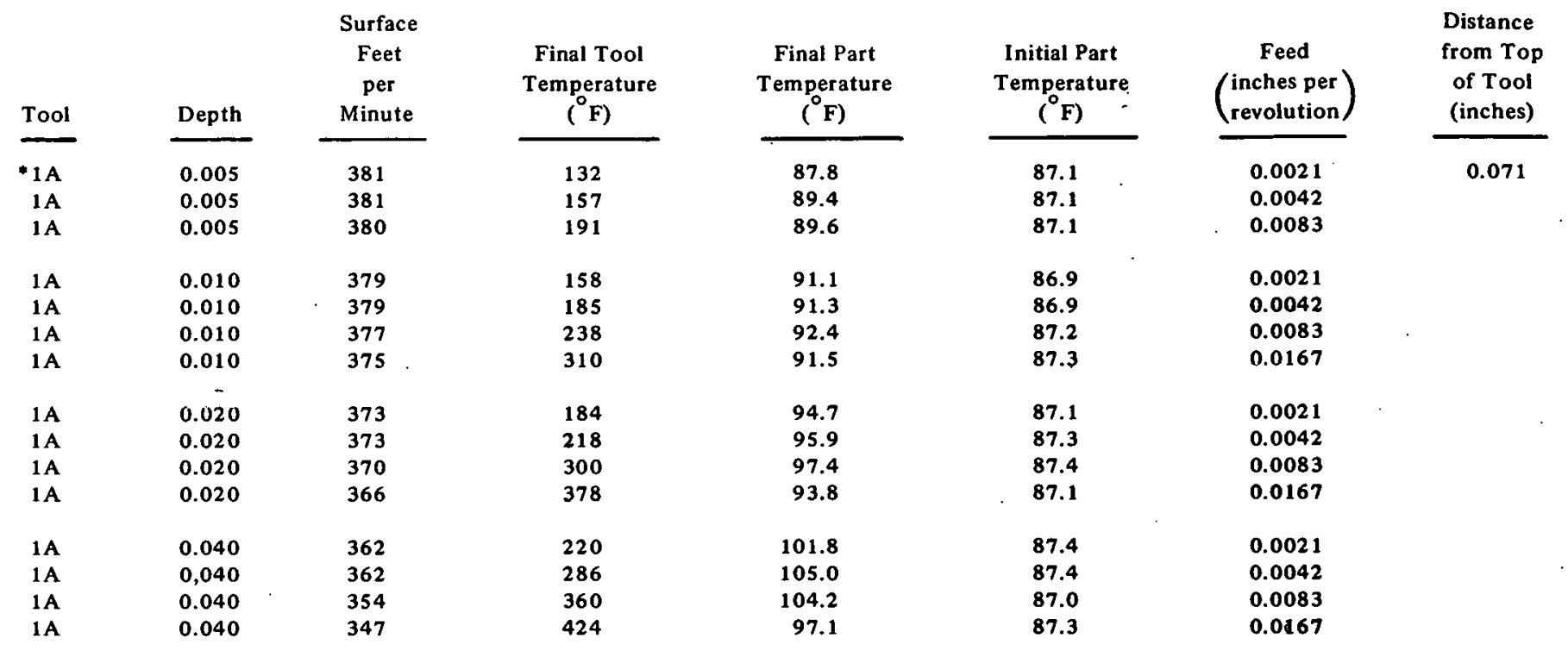

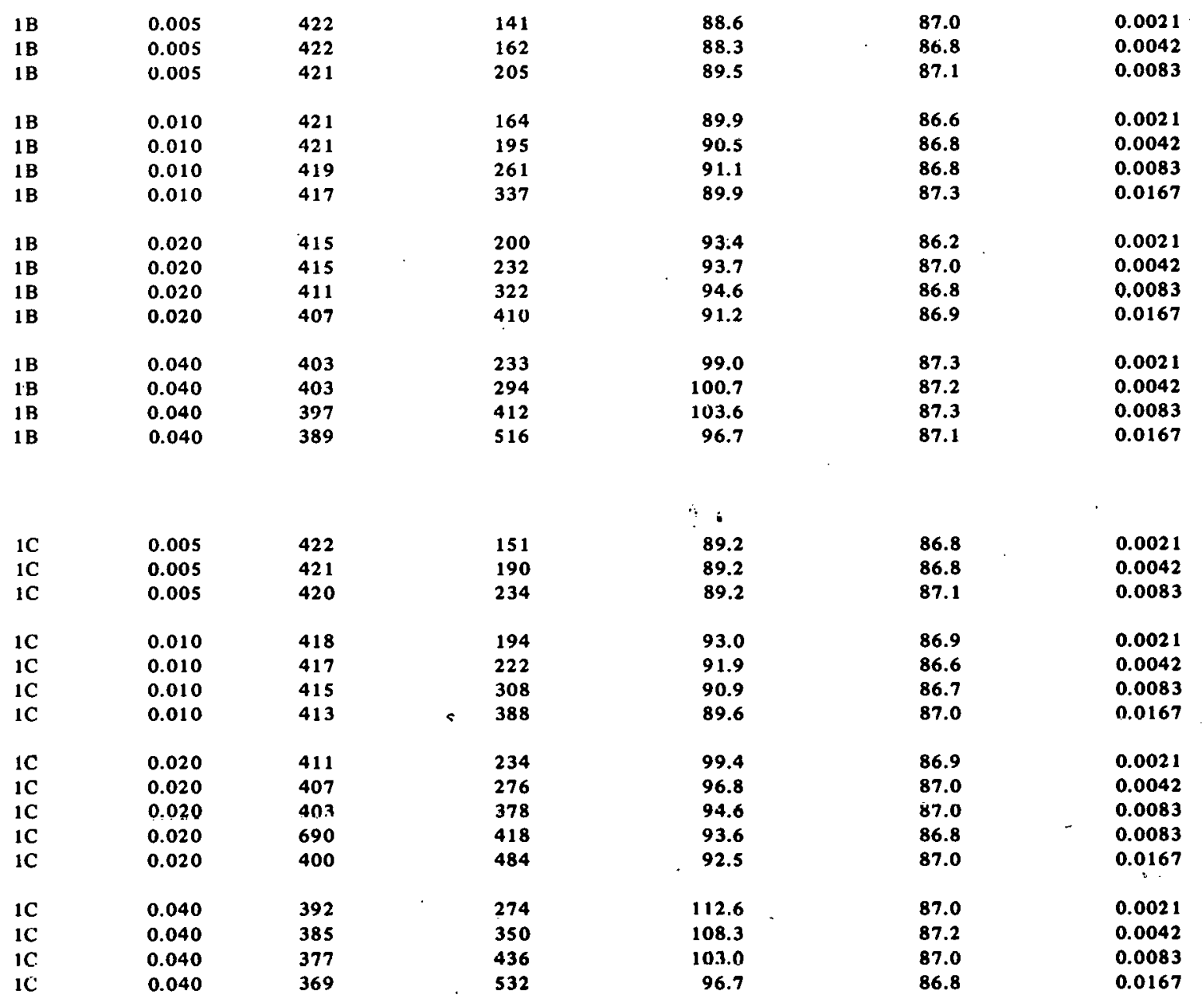

- Position 2 data are not included. 
TABLE III. (Continued)

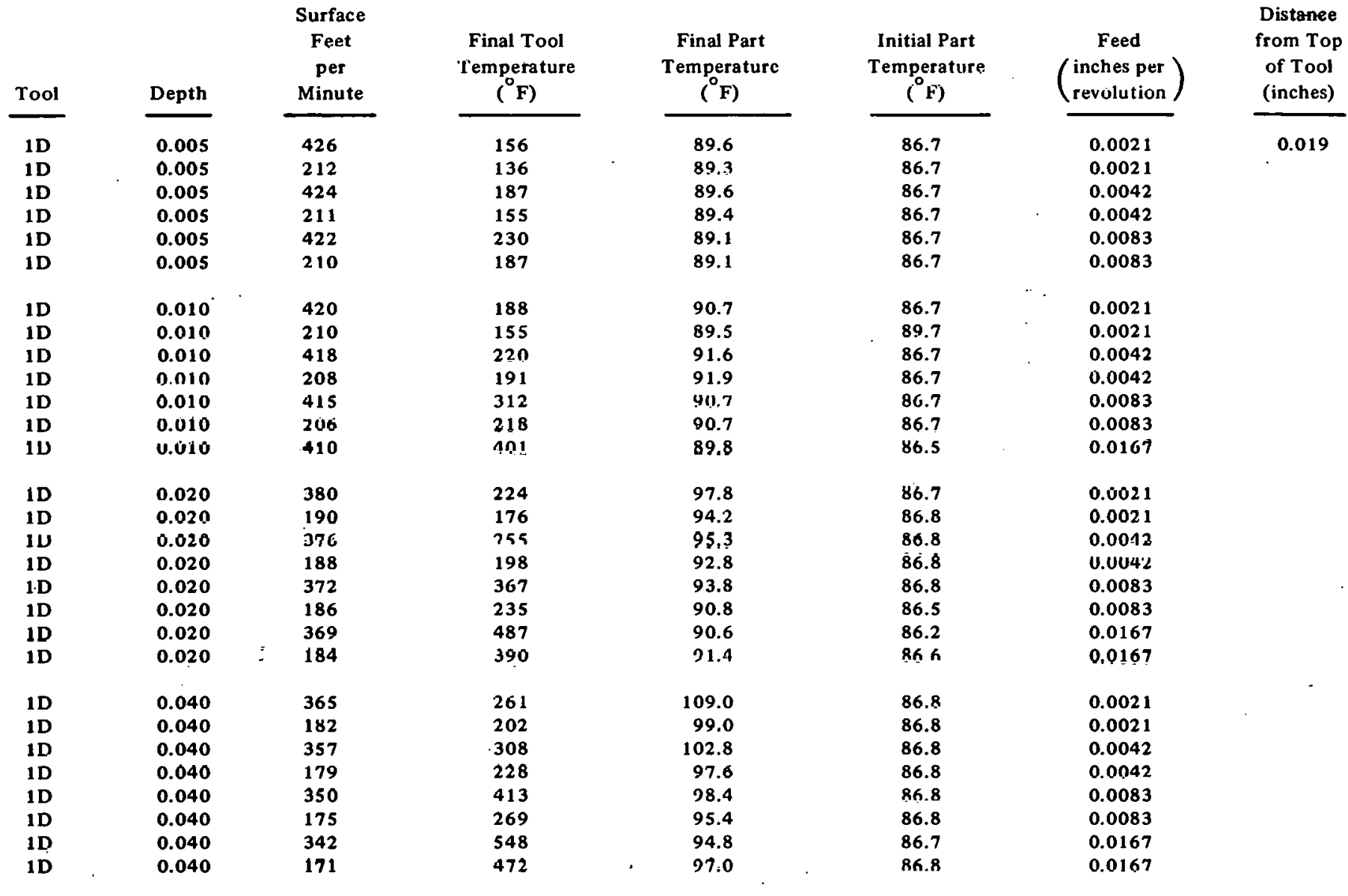

NOTE: Average distances of holes from left and right tool edges were 0.031 and 0.031 , respectively.

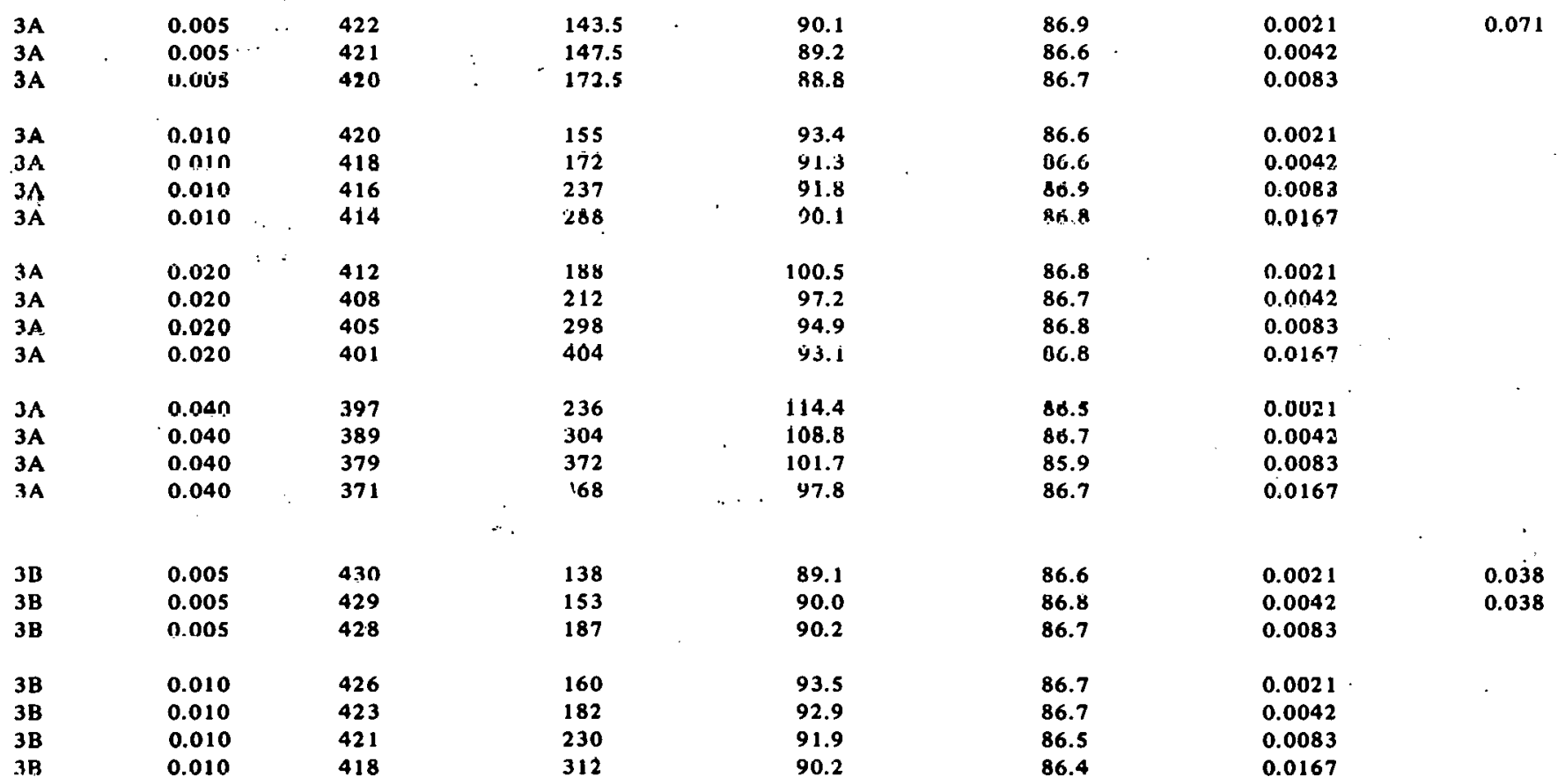


RFP-1409

TABLE III. (Continued).

\begin{tabular}{llll} 
3B & 0.020 & 415 & 195 \\
3B & 0.020 & 410 & 225 \\
3B & 0.020 & 405 & 307 \\
3B & 0.020 & 400 & 40 \\
& & & \\
3B & 0.040 & 394 & 24 \\
3B & 0.040 & 384 & 30 \\
3B & 0.040 & 374 & 384 \\
3B & 0.040 & 364 & 50 \\
\hline
\end{tabular}

$\begin{array}{rcc}101.9 & 86.6 & 0.0021 \\ 97.7 & 85.5 & 0.0042 \\ 96.1 & 86.5 & 0.0083 \\ 93.6 & 85.7 & 0.0167 \\ 116.8 & 86.8 & \\ 113.3 & 86.9 & 0.0021 \\ 107.1 & 86.7 & 0.0042 \\ 99.4 & 86.6 & 0.0083 \\ & & 0.0167\end{array}$

36. $\quad 0.005 \quad 372 \quad 140$

140

151

$\begin{array}{ll}0.005 & 369\end{array}$

0.010

0.010

0.010

0.010

368

366

365

363

0.020

0.020

0.020

0.020

361

358

363

349

0.040

0.040

0.040

0.040

346

338

331

320

\begin{tabular}{lll} 
3D & 0.005 & 346 \\
3D & 0.005 & 420 \\
3D & 0.005 & 346 \\
3D & 0.005 & 420 \\
3D & 0.005 & 346 \\
3D & 0.005 & 420 \\
\hline 3D & 0.010 & 343 \\
3D & 0.010 & 416 \\
3D & 0.010 & 343 \\
3D & 0.010 & 416 \\
3D & 0.010 & 340 \\
3D & 0.010 & 412 \\
3D & 0.010 & 337 \\
3D & 0.010 & 408 \\
& & \\
3D & 0.020 & 332 \\
3D & 0.020 & 405 \\
3D & 0.020 & 332 \\
3D & 0.020 & 405 \\
3D & 0.020 & 326 \\
3D & 0.020 & 397 \\
3D & 0.020 & 320 \\
3D & 0.020 & 390 \\
& & \\
3D & 0.040 & 310 \\
3D & 0.040 & 382 \\
3D & 0.040 & 310 \\
3D & 0.040 & 382 \\
3D & 0.040 & 298 \\
3D & 0.040 & 367 \\
3D & $\mathbf{0 . 0 4 0}$ & 285 \\
3D & 0.040 & 352 \\
\hline & &
\end{tabular}

195

307

402

243

384

509
89.3

89.4

89.2

94.6

92.8

91.6

90.5

102.0

98.0

96.3

93.5

114.4

109.0

104.4

98.1
86.6

86.7

86.7

86.7

86.7

86.7

86.6

86.7

86.8

86.7

86.8

86.0

86.7

86.8

86.3
0.0167

0.0042

0.0083
0.0167

.0021

0.0042

0.0021

0.0042

0.0083

0.0021

0.0042

0.0083

0.0167

0.0021

0.0042

0.0083

0.016 ?

0.0021

0.0042

0.0083

0.0167

0.021

\begin{tabular}{|lll}
\hline 89.1 & 87.0 & 0.0021 \\
89.2 & 87.0 & 0.0021 \\
89.8 & 86.9 & 0.0042 \\
89.4 & 87.0 & 0.0042 \\
89.8 & 86.9 & 0.0083 \\
90.2 & 87.0 & 0.0083 \\
91.3 & 86.8 & \\
90.5 & 87.0 & 0.0021 \\
92.6 & 87.0 & 0.0021 \\
93.2 & 87.0 & 0.0042 \\
93.1 & 87.0 & 0.0042 \\
93.5 & 87.0 & 0.0083 \\
91.7 & 87.0 & 0.0083 \\
91.2 & 86.9 & 0.0167 \\
95.2 & & 0.0167 \\
95.2 & 87.1 & 0.0021 \\
95.2 & 87.1 & 0.0021 \\
96.4 & 87.0 & 0.0042 \\
96.8 & 87.1 & 0.0042 \\
98.7 & 87.1 & 0.0083 \\
98.6 & 87.0 & 0.0083 \\
95.5 & 86.9 & 0.0167 \\
92.8 & 86.9 & 0.0167 \\
\hline 101.2 & & 0.0021 \\
103.0 & 87.0 & 0.0021 \\
104.0 & 87.1 & 0.0042 \\
108.2 & 86.8 & 0.0042 \\
111.1 & 87.0 & 0.0083 \\
108.6 & 87.0 & 0.0083 \\
100.6 & 87.0 & 0.0167 \\
99.3 & 87.2 & 0.0167
\end{tabular}

0.012

\begin{tabular}{lr}
137 & 89.1 \\
141 & 89.2 \\
155 & 89.8 \\
166 & 89.4 \\
178 & 89.8 \\
200 & 90.2 \\
& \\
158 & 91.3 \\
168 & 90.5 \\
181 & 92.6 \\
196 & 93.2 \\
223 & 93.1 \\
245 & 93.5 \\
330 & 91.7 \\
325 & 91.2 \\
& \\
182 & 95.2 \\
193 & 95.2 \\
212 & 96.4 \\
228 & 96.8 \\
318 & 98.7 \\
335 & 98.6 \\
411 & 95.5 \\
430 & 92.8 \\
& \\
222 & 101.2 \\
237 & 103.0 \\
280 & 104.0 \\
330 & 108.2 \\
420 & 111.1 \\
440 & 108.6 \\
538 & 100.6 \\
529 & 99.3 \\
\hline 30 &
\end{tabular}

0.002

0.0042

0.0042

0.0083

0.0021

0.0042

0.0042

0.0083

0.0167

0.0021

0.0021

0.0042

0.0083

0083

0167

0.0021

0.0021

0.0042

0.0083

0.0167

0.0167

NOTE: Average distances of holes from left and right tool edges were 0.062 and 0.046 , respectively. 
TABLE III. (Continued).

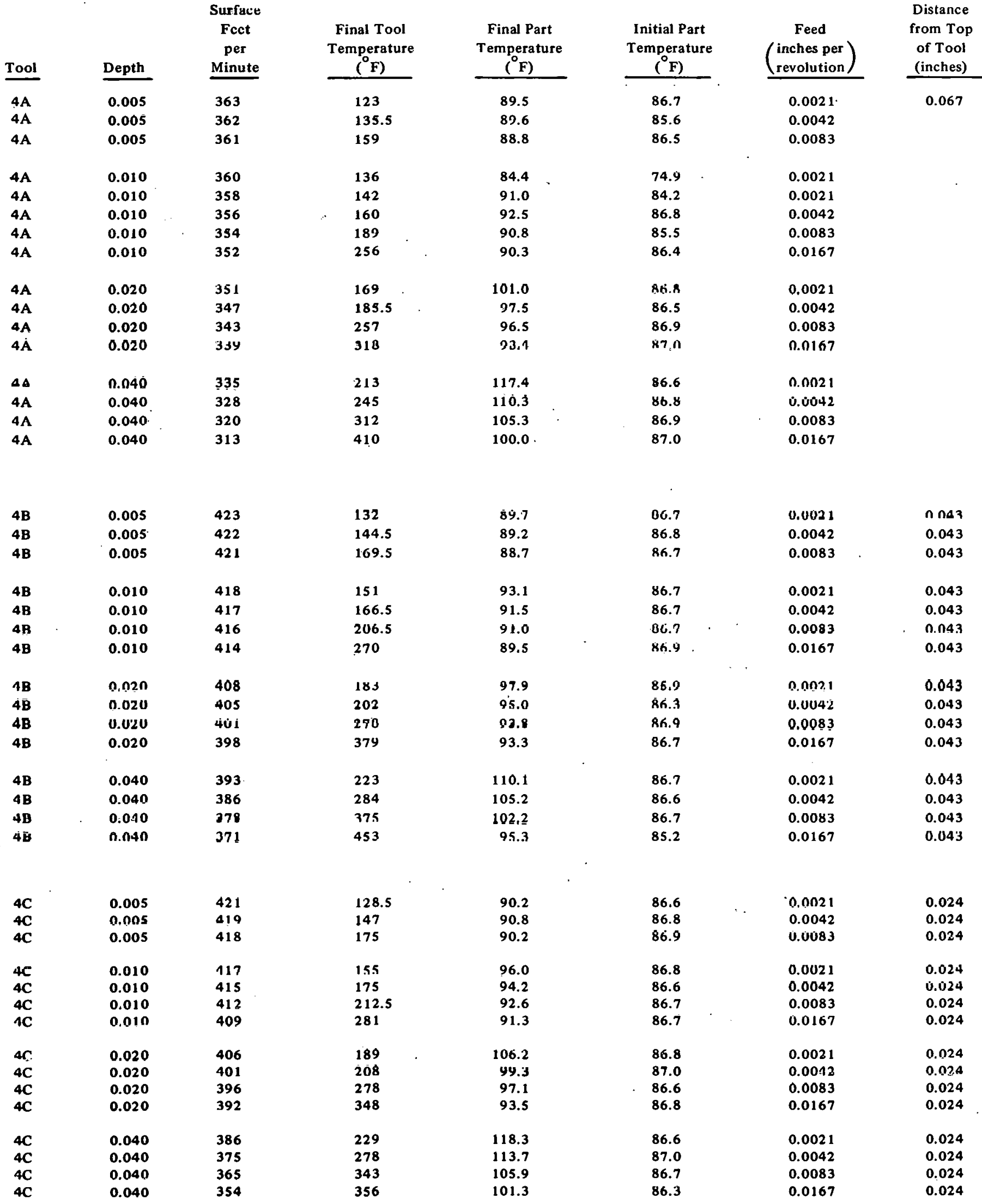


TABLE III. (Continued).

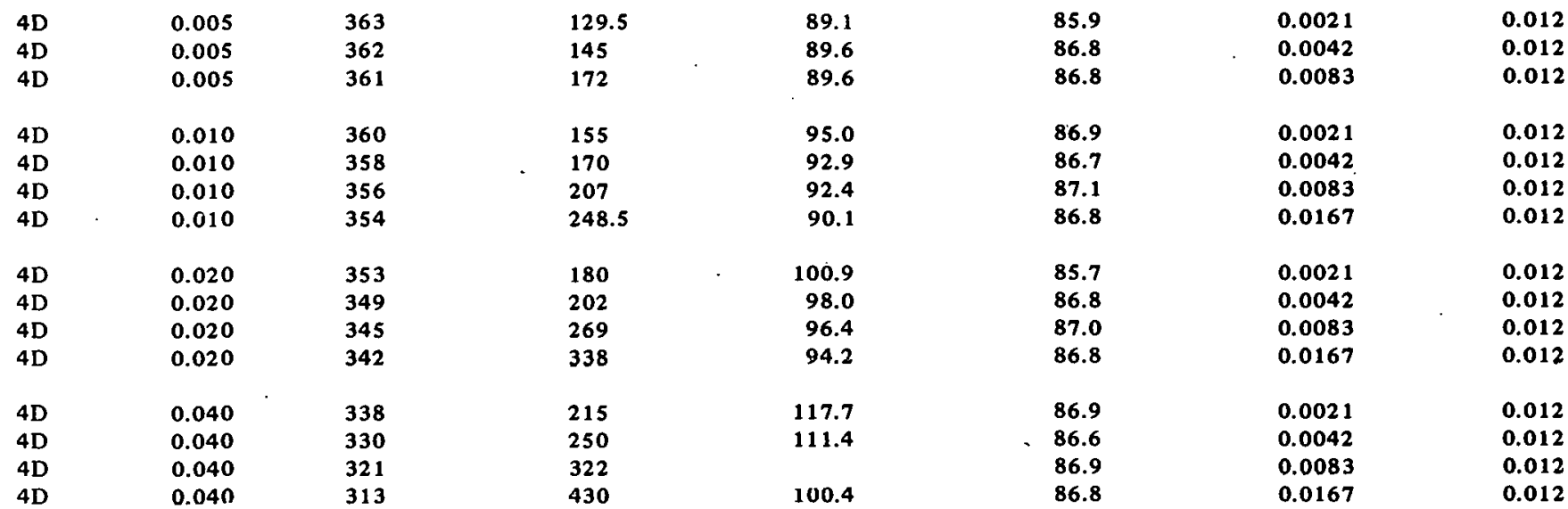

NOTE: Average distances of holes from left and right tool edges were 0.094 and 0.092 , respectively.

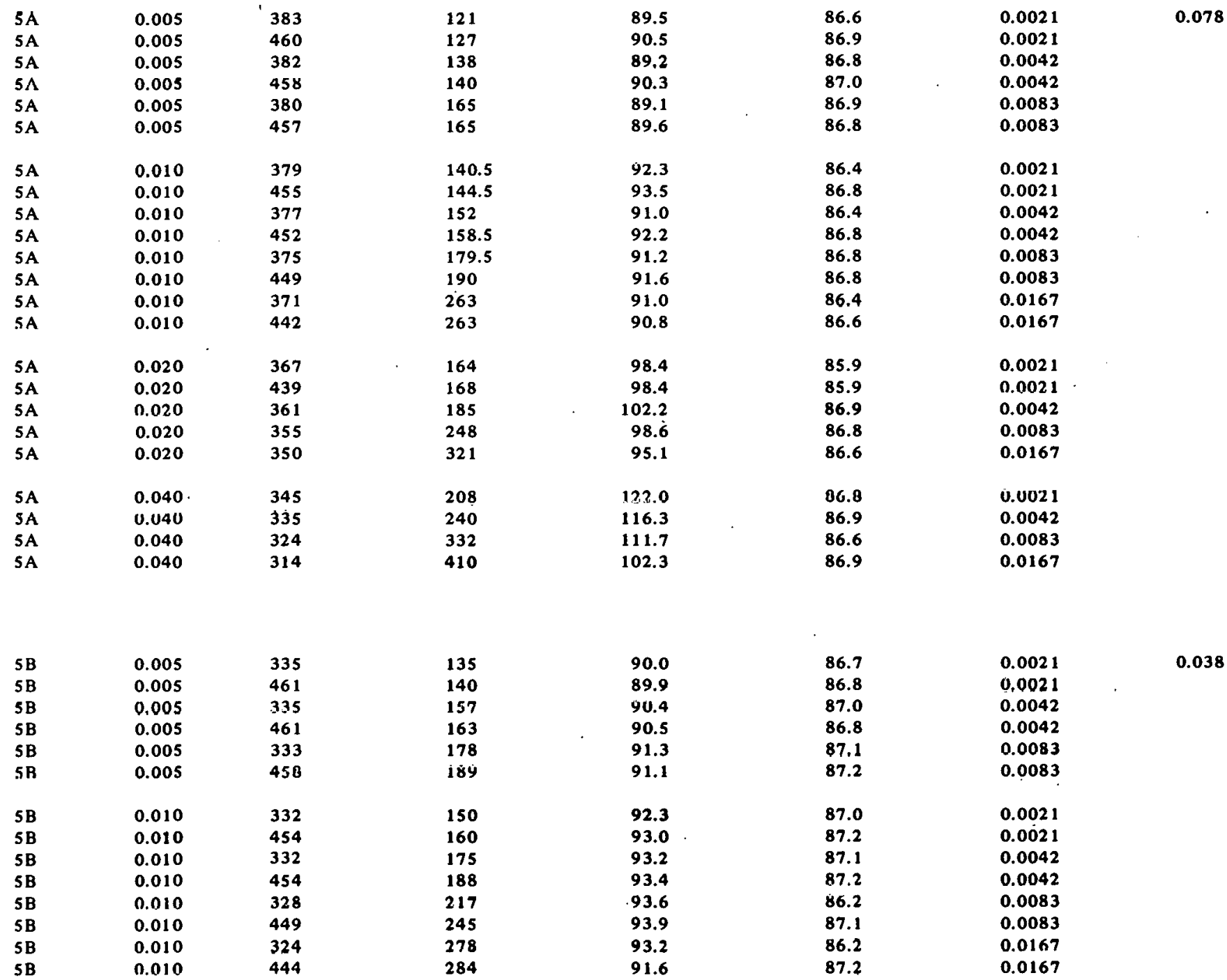


TABLE III. (Continued).

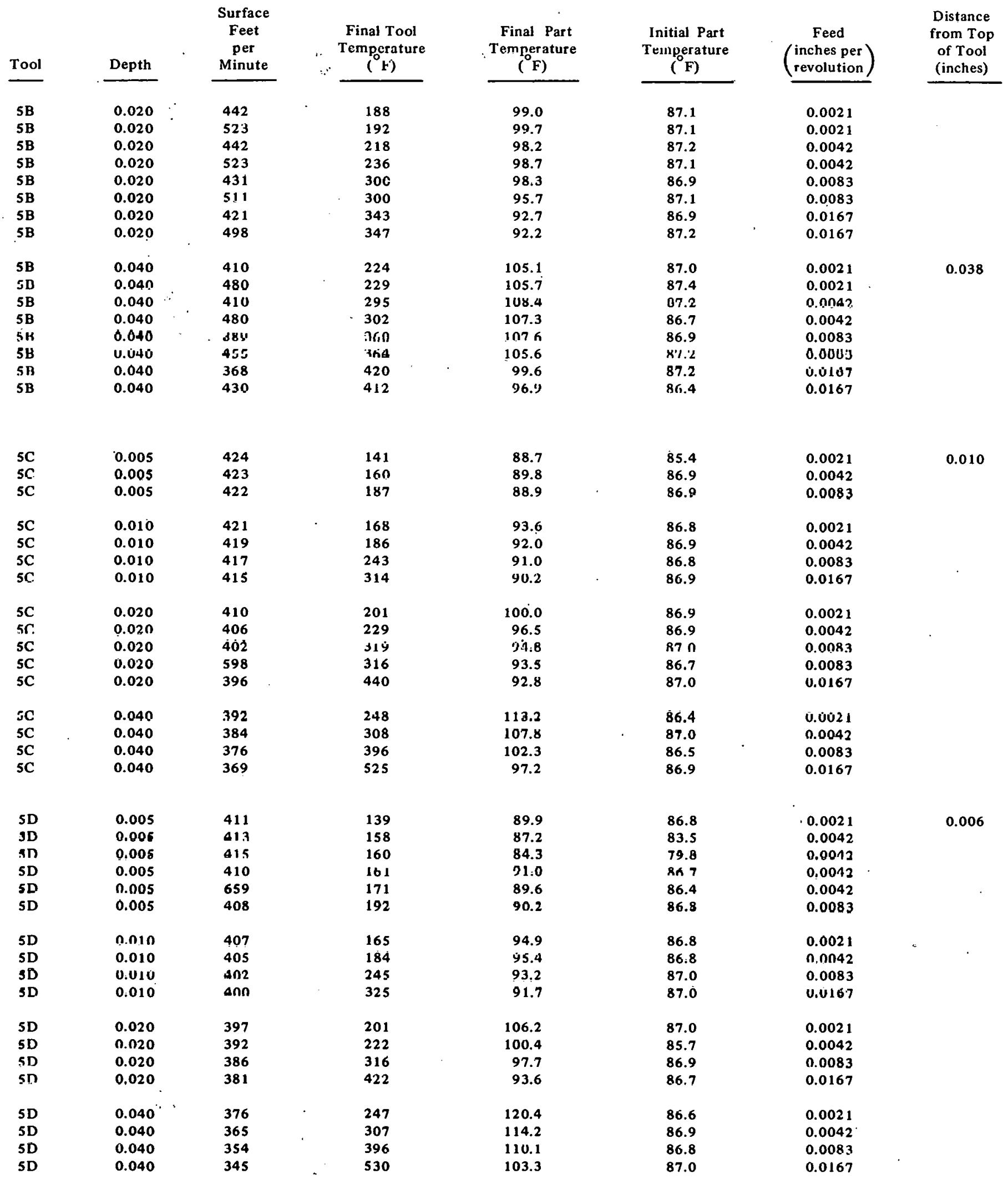


TABLE III. (Continued).

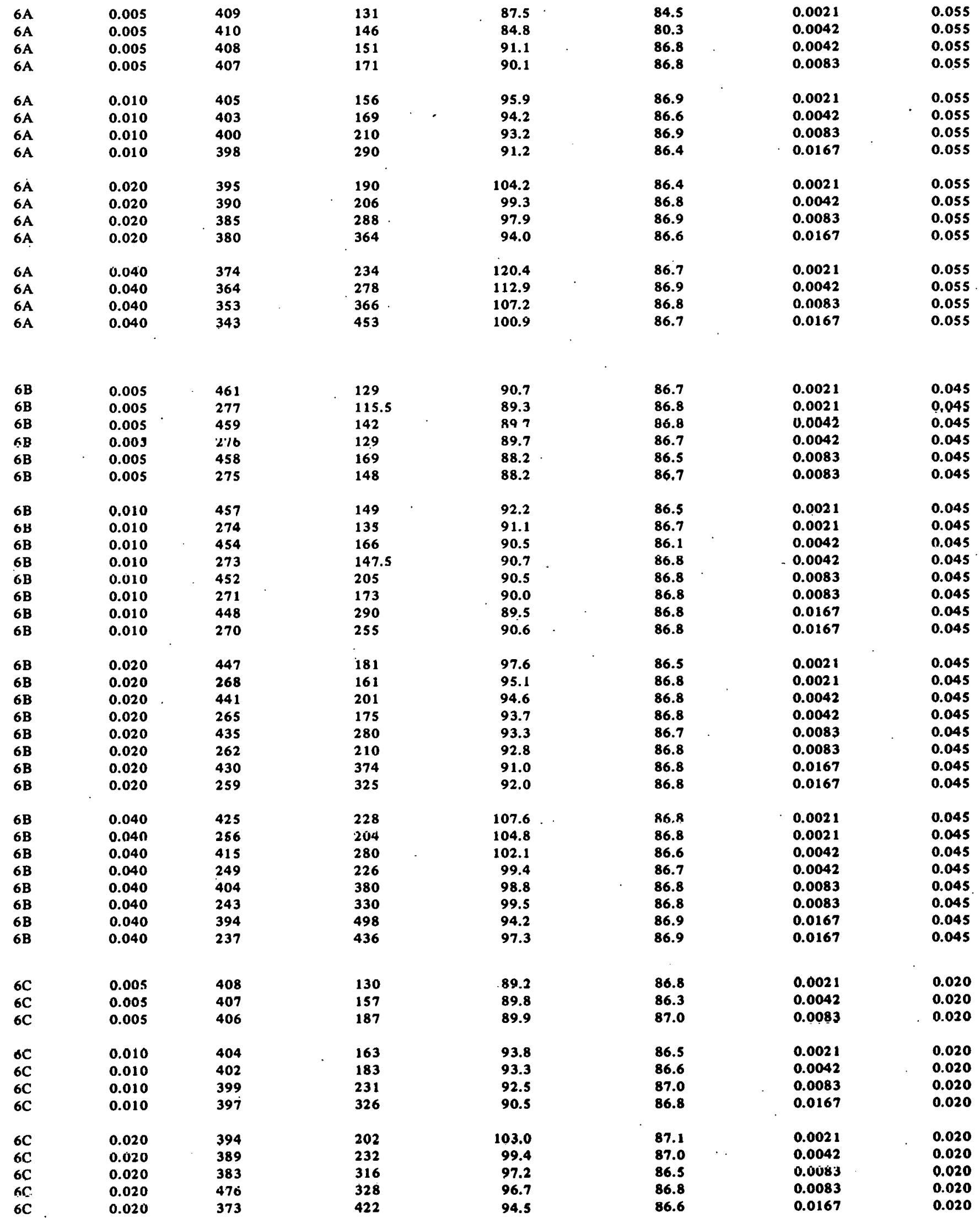


TABLE III. (Continued).

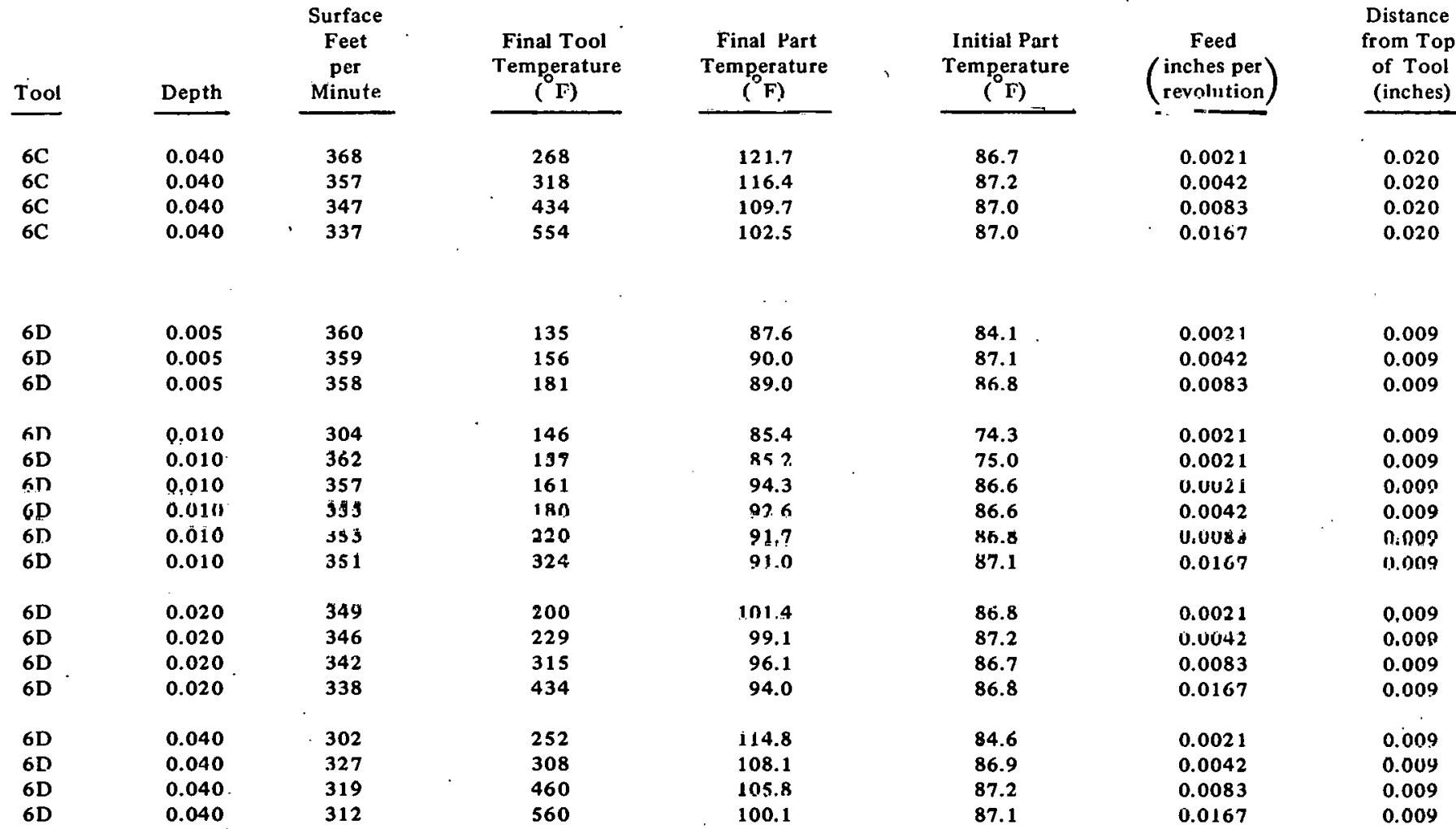

NOTE: Average distances of holes from left and right tool edges werc 0.020 and 0.075 , respectively. .

\begin{tabular}{|c|c|c|c|c|c|c|c|}
\hline $7 \mathrm{~A}$ & 0.005 & 361 & 125 & $8 \hat{8.0}$ & $87 . n$ & 0,0021 & 0.067 \\
\hline $7 \mathrm{~A}$ & 0.005 & 361 & 144 & 89.4 & 87.0 & 0.0042 & 0.067 \\
\hline $7 \mathrm{~A}$ & 0.005 & 360 & 179 & 90.2 & 87.0 & 0.0083 & 0.067 \\
\hline $7 \mathrm{~A}$ & 0.010 & 359 & 144 & 90.4 & 86.6 & 0.0021 & ก.067 \\
\hline IA & 0.010 & .599 & 171 & 90.6 & 86.1 & 0.0042 & 0.067 \\
\hline $7 \mathrm{~A}$ & 0.010 & 357 & 226 & 乌2.5 & 86.7 & 0,0083 & 0.067 \\
\hline $7 \mathrm{~A}$ & 0.010 & 355 & 320 & 90.9 & 86.3 & 0.0167 & $0.06 \%$ \\
\hline $7 \mathrm{~A}$ & 0.020 & 353 & 181 & 94.2 & 87.0 & 0.0021 & 0.067 \\
\hline $7 \mathrm{~A}$ & 0.020 & 353 & 222 & 96.1 & 86.8 & 0.0042 & 0.067 \\
\hline $7 \mathrm{~A}$ & 0.020 & 350 & 312 & 97.3 & 87.0 & 0.0083 & 0.067 \\
\hline $7 \Lambda$ & 0.020 & 346 & 354 & 94.3 & 87.0 & 0.0167 & 0.067 \\
\hline $7 \mathrm{~A}$ & 0.040 & 342 & 216 & 101.1 & 86.9 & $0.002 \mathrm{i}$ & 0.067 \\
\hline $7 \mathrm{~A}$ & 0.040 & 342 & 292 & 104.9 & 86.4 & 0.0042 & 0.067 \\
\hline $7 \mathrm{~A}$ & 0.040 & 335 & 362 & 107,5 & 86.9 & 0.0083 & 0.067 \\
\hline IA & 0.040 & 32.7 & 406 & 98.5 & 87.0 & 0.0167 & 0.067 \\
\hline 7B & 0.005 & 339 & 125 & 88.9 & 87.0 & 0.0021 & n.nag \\
\hline 7B & 0.005 & 339 & 141 & 88.4 & 87.0 & 0.0042 & n.036 \\
\hline 7B & 0.005 & 338 & 170 & 89.3 & 86.8 & 0.0083 & 0.036 \\
\hline $7 \mathrm{~B}$ & 0.010 & 337 & 146 & 89.9 & 86.7 & 0.0021 & 0.036 \\
\hline $7 \mathrm{~B}$ & 0.010 & 337 & 170 & 89.6 & 86.6 & 0.0042 & 0.036 \\
\hline $7 \mathrm{~B}$ & 0.010 & 335 & 210 & 90.9 & 86.9 & 0.0083 & 0.036 \\
\hline $7 \mathrm{~B}$ & 0.010 & 333 & 285 & 90.6 & 87.0 & 0.0167 & 0.036 \\
\hline $7 \mathrm{~B}$ & 0.020 & 331 & 173 & 93.5 & 87.0 & 0.0021 & 0.036 \\
\hline $7 B$ & 0.020 & 331 & 194 & 94.0 & 87.0 & 0.0042 & 0.036 \\
\hline 7B & 0.020 & 327 & 264 & 96.1 & 86.8 & 0.0083 & 0.036 \\
\hline 7B & 0.020 & 323 & 338 & 92.2 & 86.0 & 0.0167 & 0.036 \\
\hline
\end{tabular}


TABLE III. (Continued).

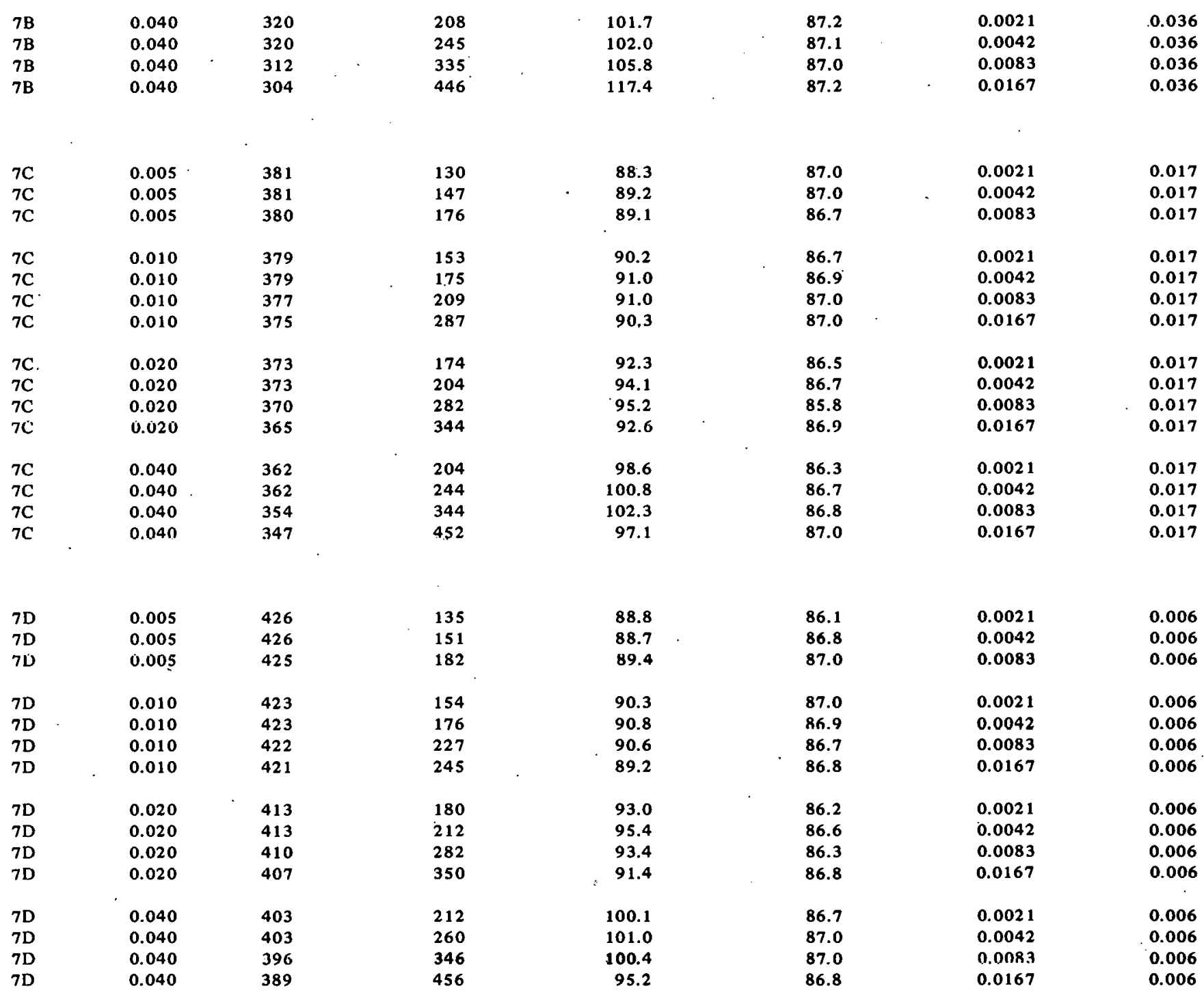

NOTE: Average distances of holes from left and right tool edges were 0.105 and 0.028 , respectively.

\begin{tabular}{|c|c|c|c|c|c|c|c|}
\hline $8 \mathrm{~A}$ & 0.005 & 343 & 124 & 89.0 & 86.8 & 0.0021 & 0.066 \\
\hline $8 \mathrm{~A}$ & 0.005 & 343 & 139 & 90.1 & 87.0 & 0.0042 & 0.066 \\
\hline $8 A$ & 0.005 & 342 & 166 & 90.9 & 87.1 & 0.0083 & 0.066 \\
\hline $8 \mathrm{~A}$ & 0.010 & 341 & 141 & 91.5 & 86.9 & 0.0021 & 0.066 \\
\hline $8 A$ & 0.010 & 341 & 161 & 93.1 & 87.2 & 0.0042 & 0.066 \\
\hline $8 \mathrm{~A}$ & 0.010 & 339 & 212 & 93.9 & 87.0 & 0.0083 & 0.066 \\
\hline $\mathbf{\gamma A}$ & 0.010 & 337 & 292 & 93.5 & 86.9 & 0.0167 & 0.066 \\
\hline $8 \mathrm{~A}$ & 0.020 & 336 & 174 & 97.6 & 87.0 & 0.0021 & 0.066 \\
\hline $8 \mathrm{~A}$ & 0.020 & 336 & 208 & 99.4 & 87.0 & 0.0042 & 0.066 \\
\hline $8 \mathrm{~A}$ & 0.020 & 332 & 278 & 100.0 & 86.9 & 0.0083 & 0.066 \\
\hline $8 \mathrm{~A}$ & 0.020 & 324 & 364 & 98.6 & 86.5 & 0.0167 & 0.066 \\
\hline $8 \mathrm{~A}$ & 0.040 & 321 & 218 & 107.6 & 86.9 & 0.0021 & 0.066 \\
\hline $8 \AA$ & 0.040 & 321 & 270 & 110.2 & 86.9 & 0.0042 & 0.066 \\
\hline $\mathbf{8 A}$ & 0.040 & 313 & 370 & 112.6 & 86.1 & 0.0083 & 0.066 \\
\hline $8 \mathrm{~A}$ & 0.040 & 306 & 416 & 100.7 & 86.5 & 0.0167 & 0.066 \\
\hline $8 \mathrm{~A}$ & 0.040 & 351 & 275 & 109.7 & 87.3 & 0.0042 & 0.066 \\
\hline
\end{tabular}


TABLE III. (Continued).

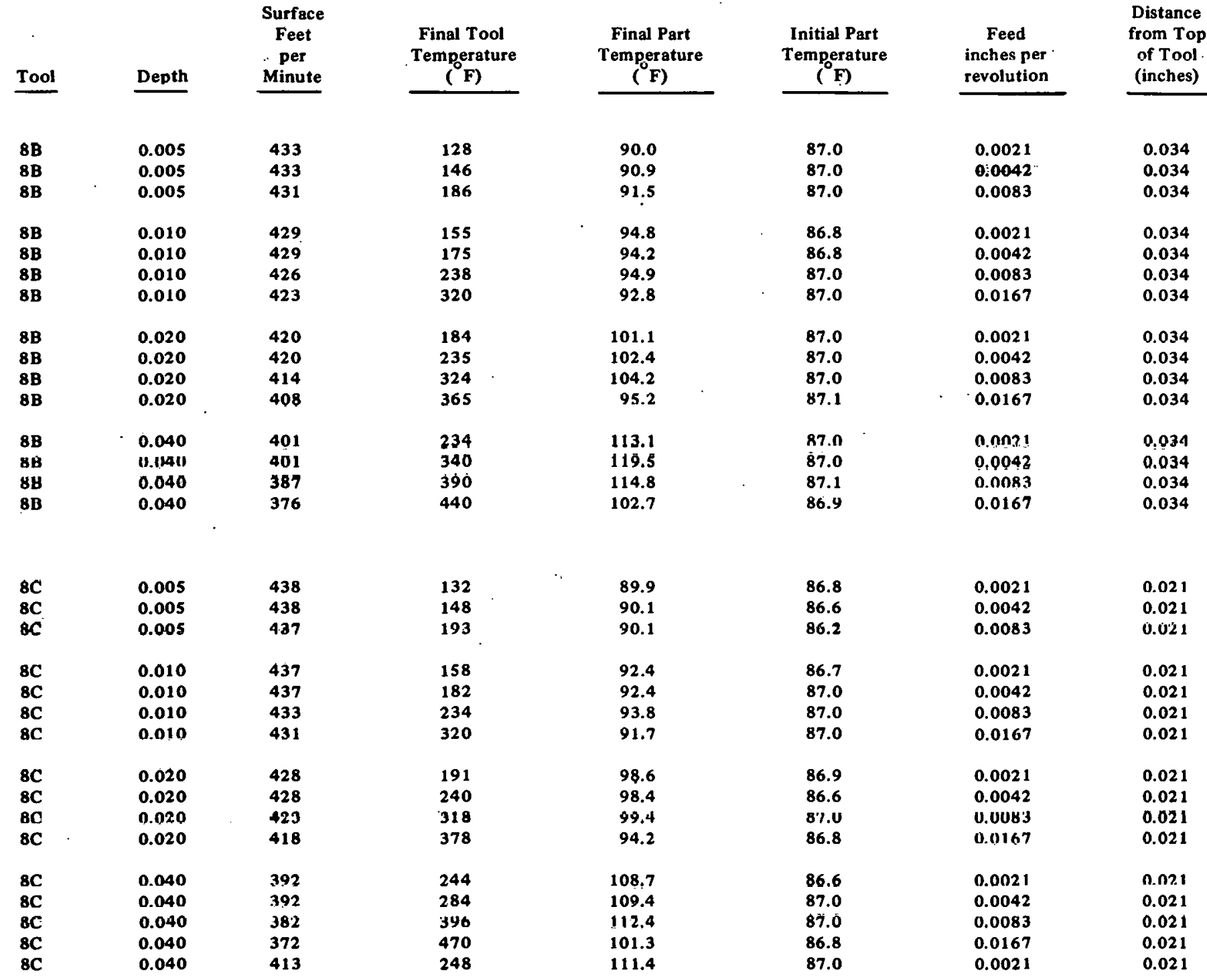

\begin{tabular}{|c|c|c|c|c|c|c|c|}
\hline 8D & 0.005 & 407 & 131 & 87.6 & RS 8 & 0.0021 & 0.001 \\
\hline 8D & 0.005 & 407 & 152 & 88.4 & 85.7 & 0.0042 & 0.001 \\
\hline 8D & 0.005 & 405 & 187 & 89.1 & 86.6 & 0.0083 & 0.001 \\
\hline 8D & 0.010 & 404 & 153 & 90.4 & 86.6 & 0.0021 & 0.001 \\
\hline 8D & 0.010 & 404 & 175 & 89.5 & 86.5 & 0.0042 & 0.001 \\
\hline 8D & 0.010 & 401 & 243 & 92.8 & 86.8 & 0.0083 & 0.001 \\
\hline 8D & 0.010 & 400 & 280 & 89.7 & 86.2 & 0.0167 & 0.001 \\
\hline 8D & 0.020 & 397 & 195 & 95.8 & 86.0 & 0.0021 & 0.001 \\
\hline 8D & 0.020 & 397 & 220 & 96.4 & 86.8 & 0.0042 & 0.001 \\
\hline 8D & 0.020 & 392 & 305 & 96.8 & 86.8 & 0.0083 & 0.001 \\
\hline 8D & 0.020 & 388 & 357 & 93.0 & 86.6 & 0.0167 & 0.001 \\
\hline 80 & 0.040 & 382 & 234 & 105.4 & 87.0 & 0.0021 & 0.001 \\
\hline 8D & 0.040 & 382 & 286 & 106.4 & 86.8 & 0.0042 & 0.001 \\
\hline 8D & 0.040 & 372 & 395 & 106.0 & 86.8 & 0.0083 & 0.001 \\
\hline 8D & 0.040 & 363 & 482 & 99.4 & 86.9 & 0.0167 & 0.001 \\
\hline
\end{tabular}


ILLUSTRATIONS

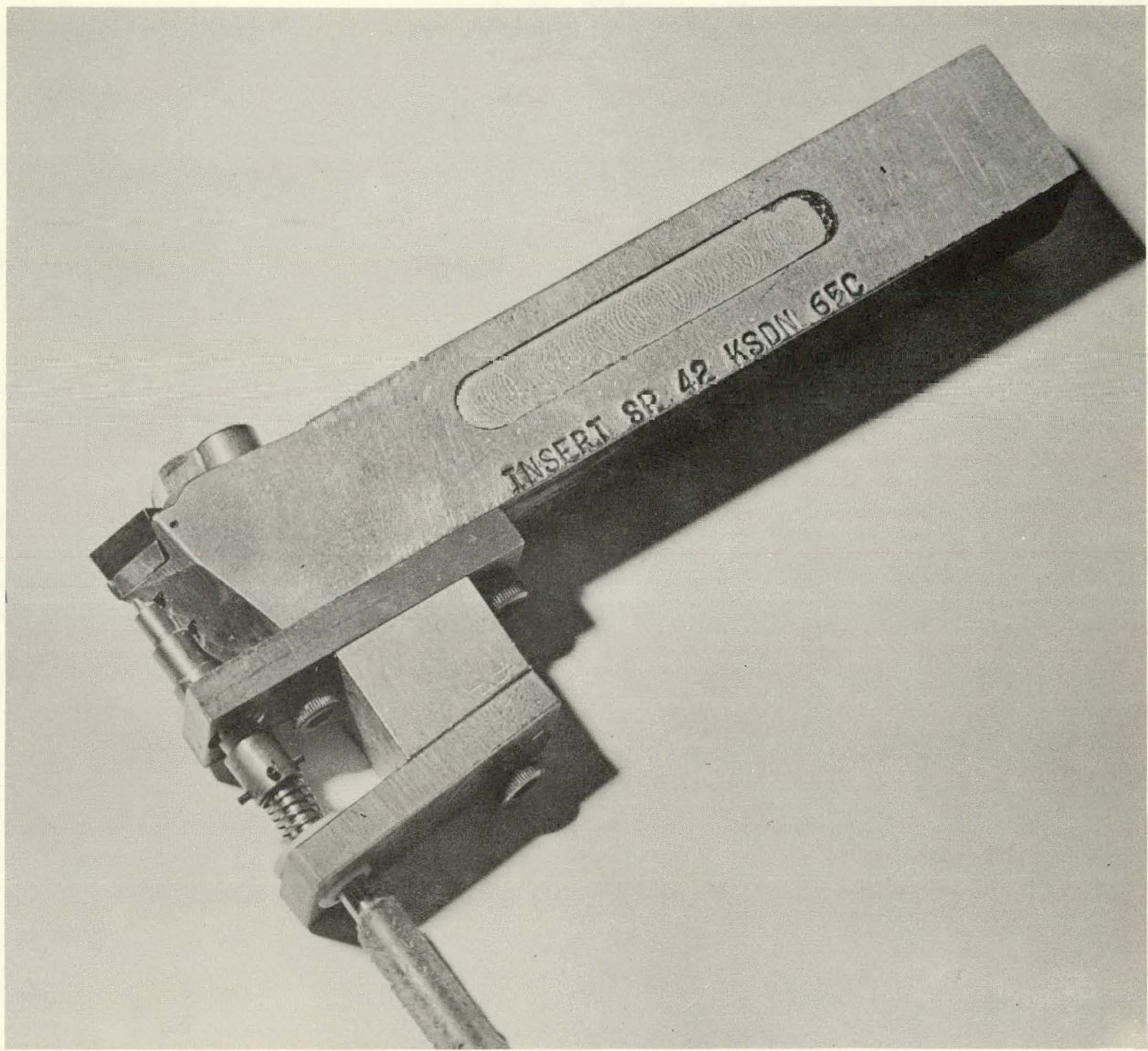

$13490-7$

FIGURE 1. Assembled Tool and Thermocouple in Place. 


$$
\text { RFP-1409 }
$$


RFP-1409

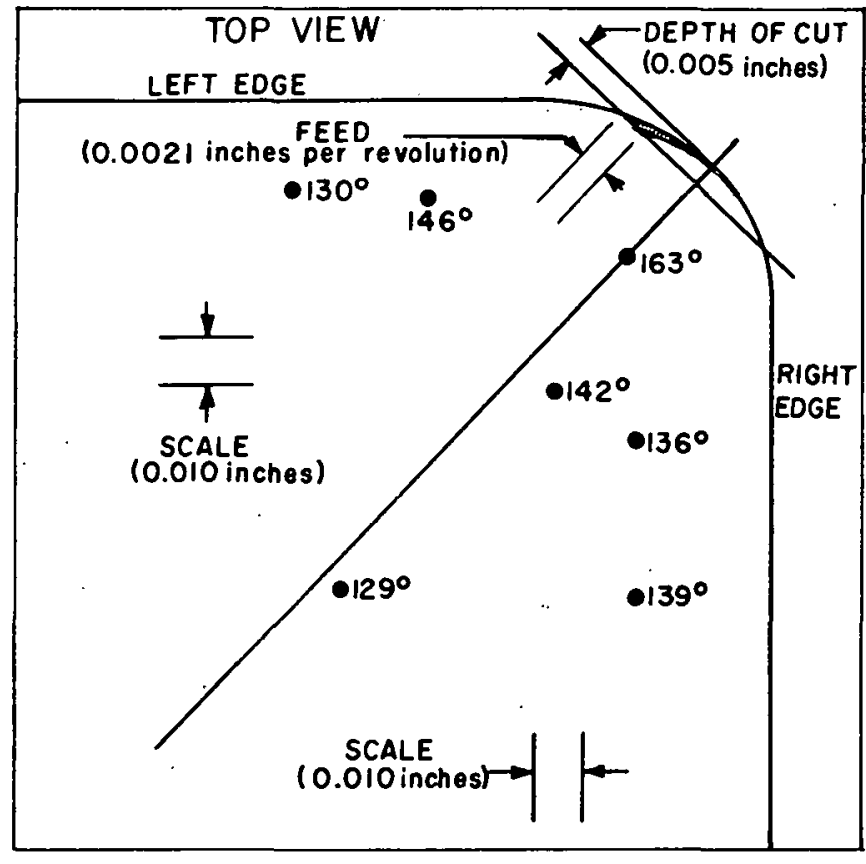

FIGURE 3. Surface Temperature Distribution. (Shaded portions of figure show amount of metal being removed.)

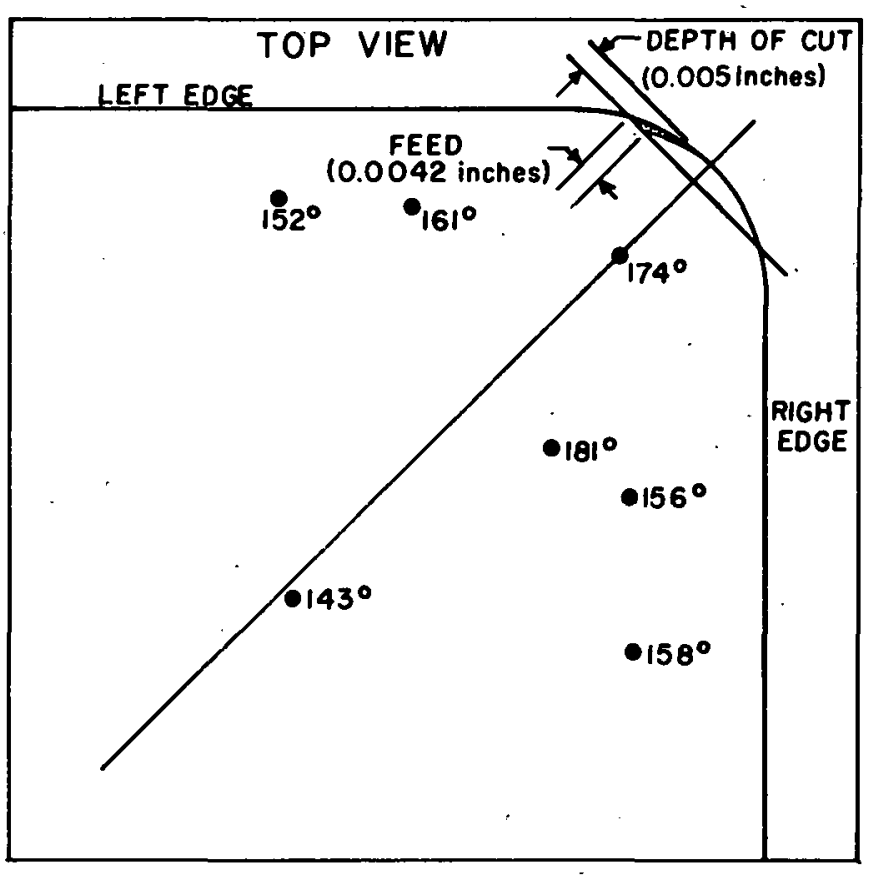

FIGURE 4. Surface Tèmperature Distribution.
FIGURE 5. Surface Temperature Distribution.

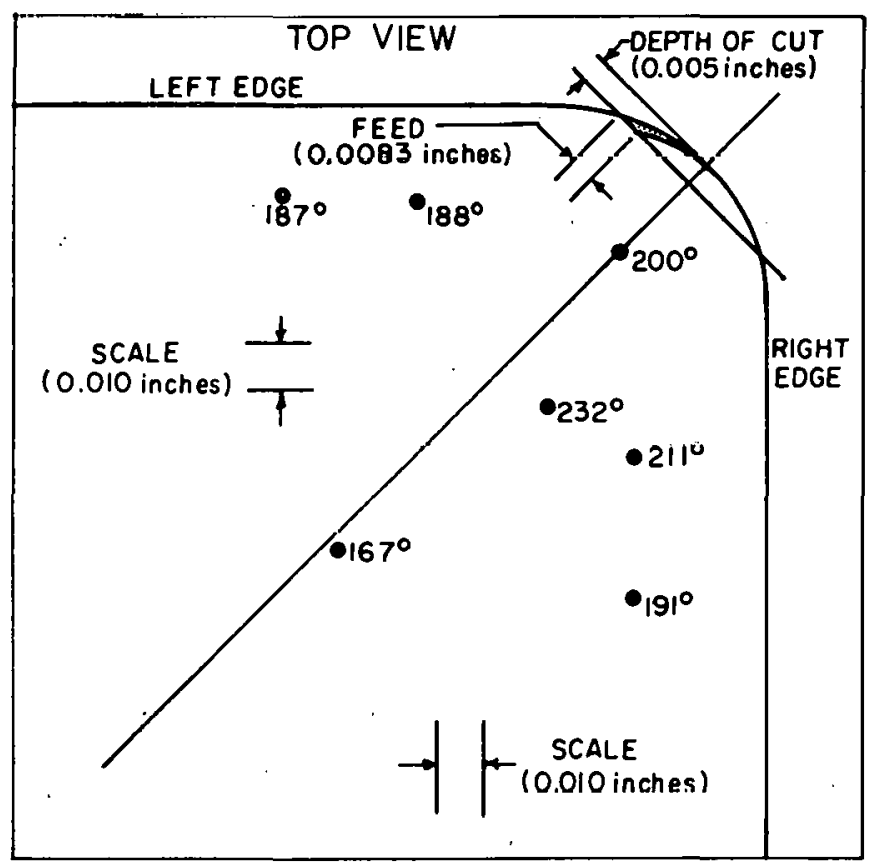

FIGURE 6. Surface Temperature Distribution.

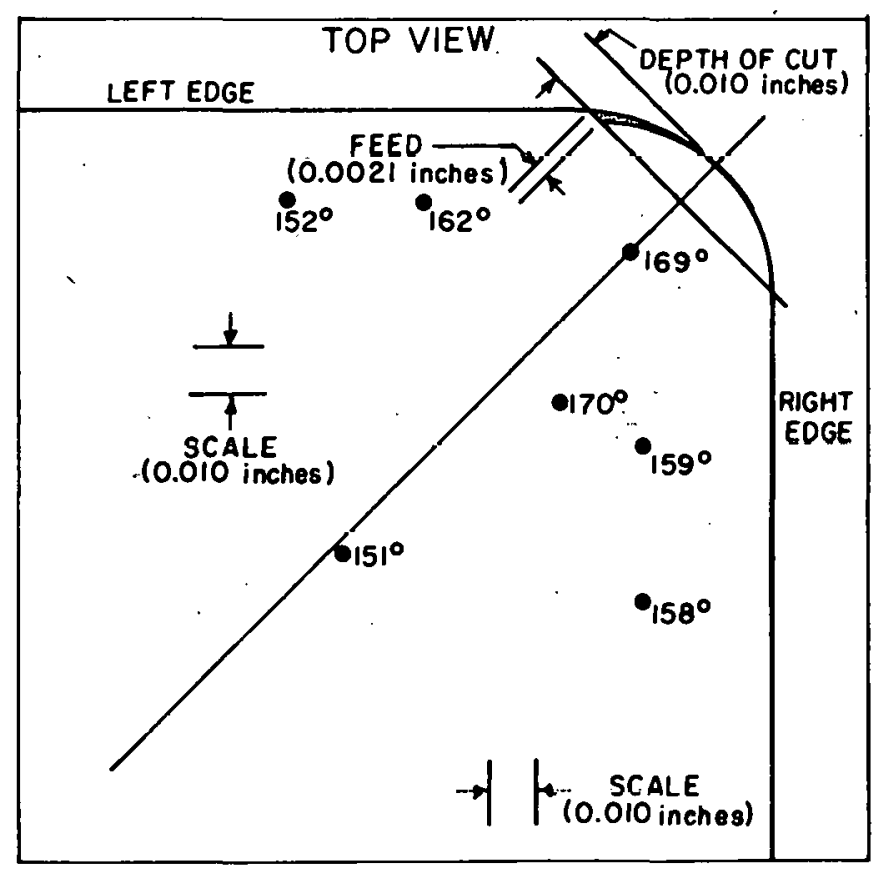


RFP-1409

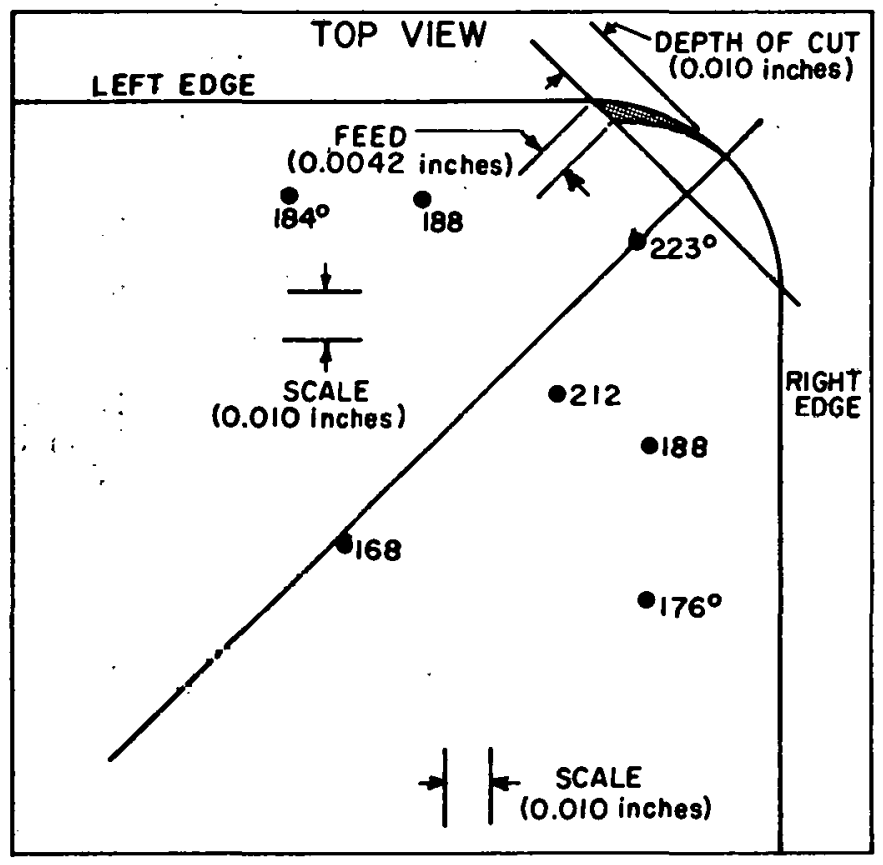

FIGURE 7. Surface Temperature Distribution.

FIGURE 9. Surface Temperature Distribütion.
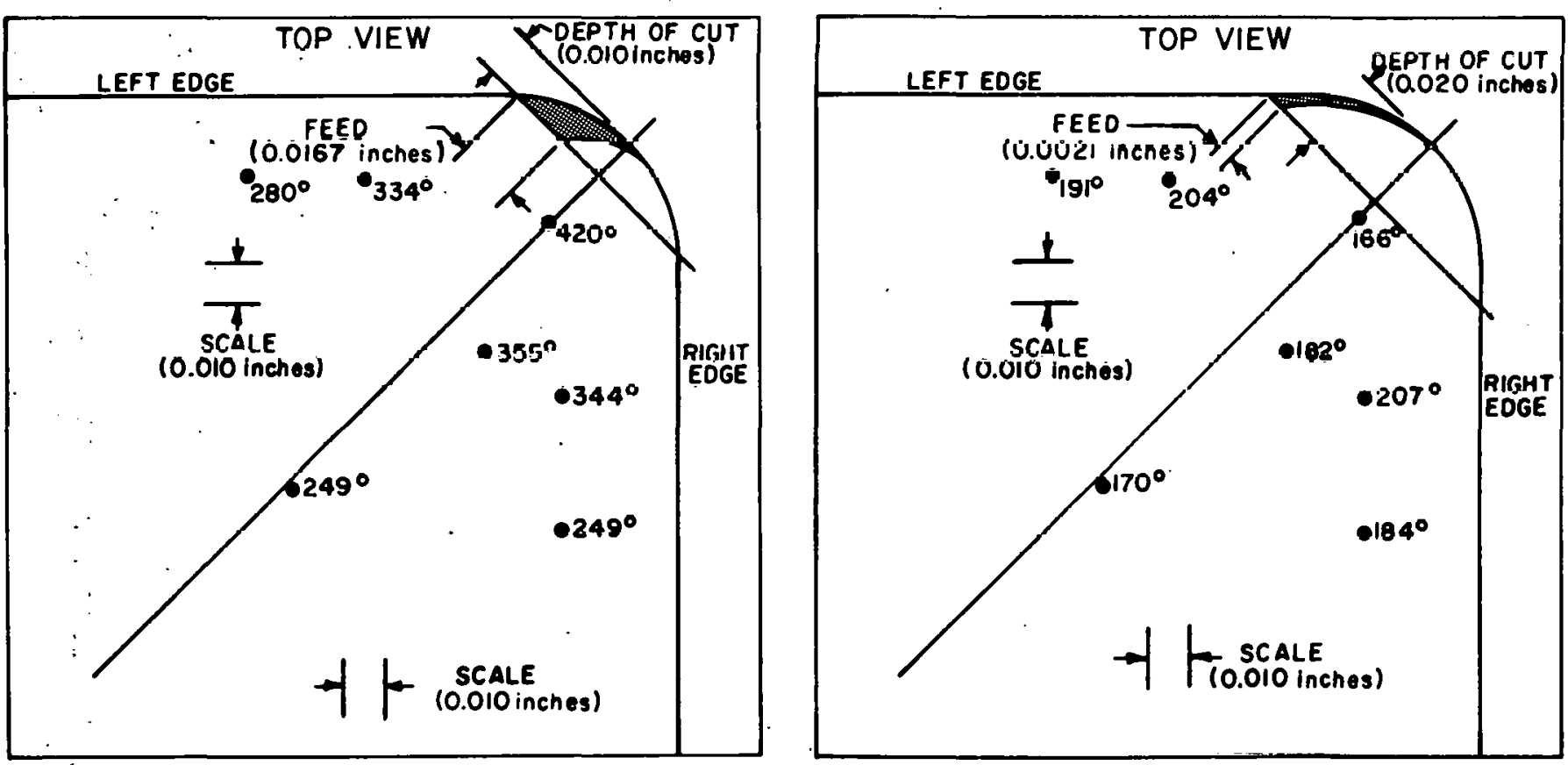


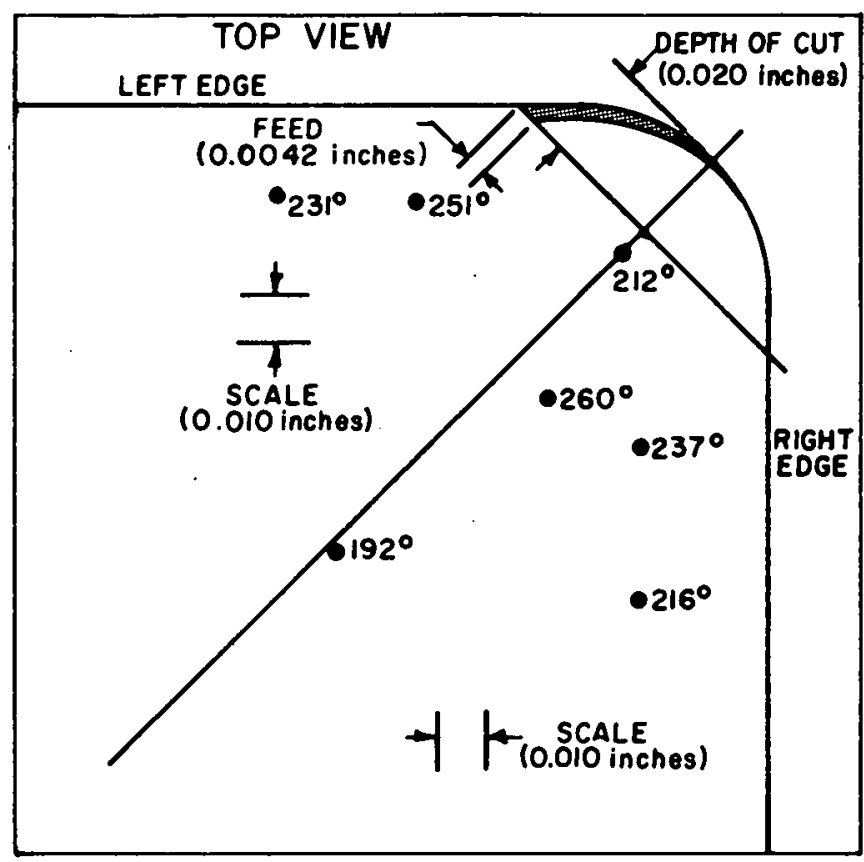

FIGURE 11. Surface Temperature Distribution.

FIGURE 13. Surface Temperature Distribution.

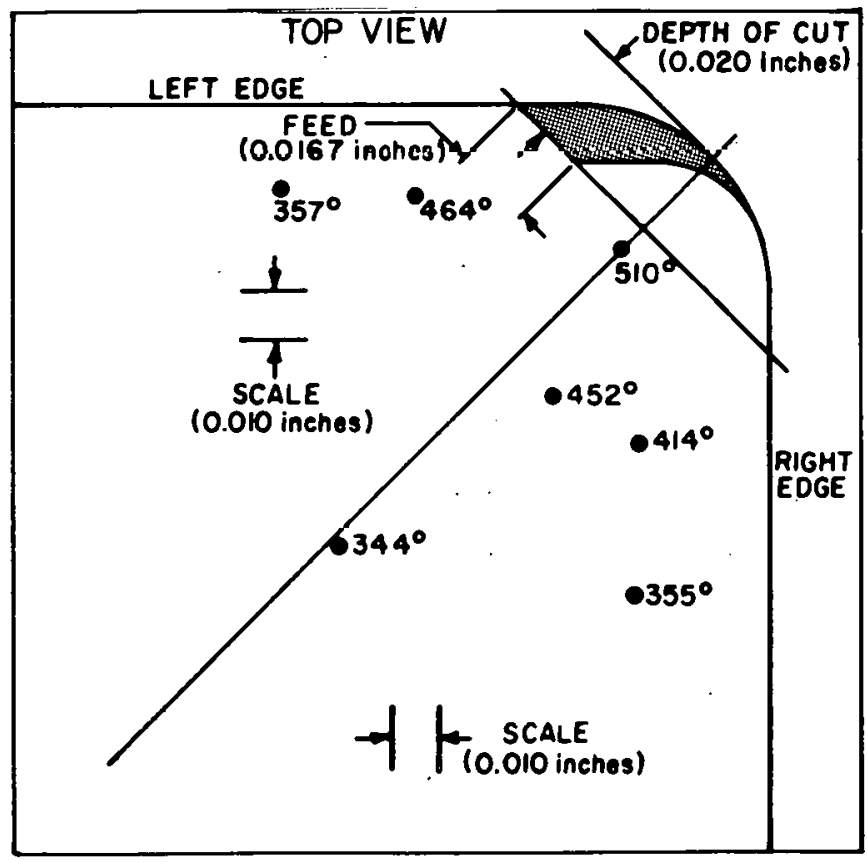

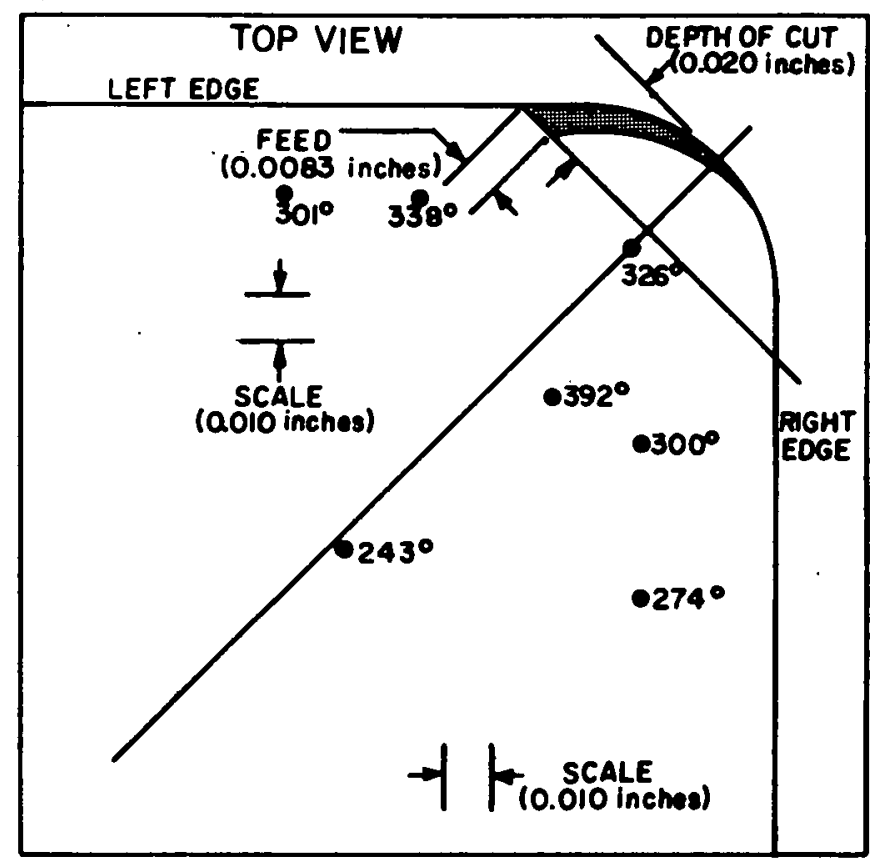

FIGURE 12. Surface Temperature Distribution. ;

FIGURE 14. Surface Temperature Distribution.

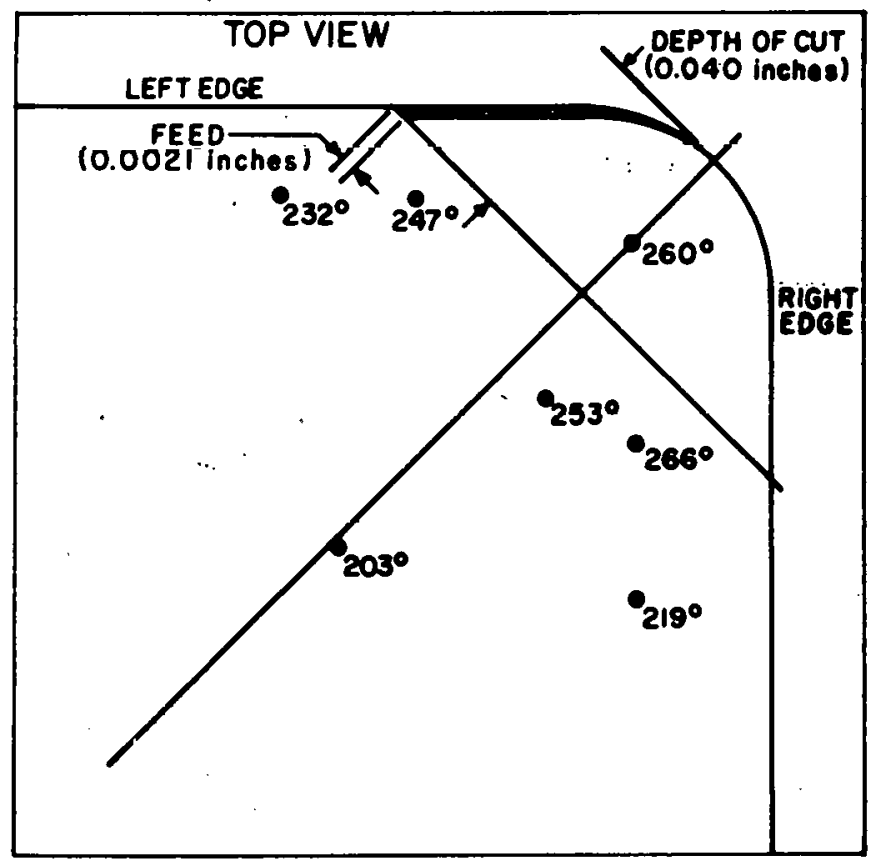




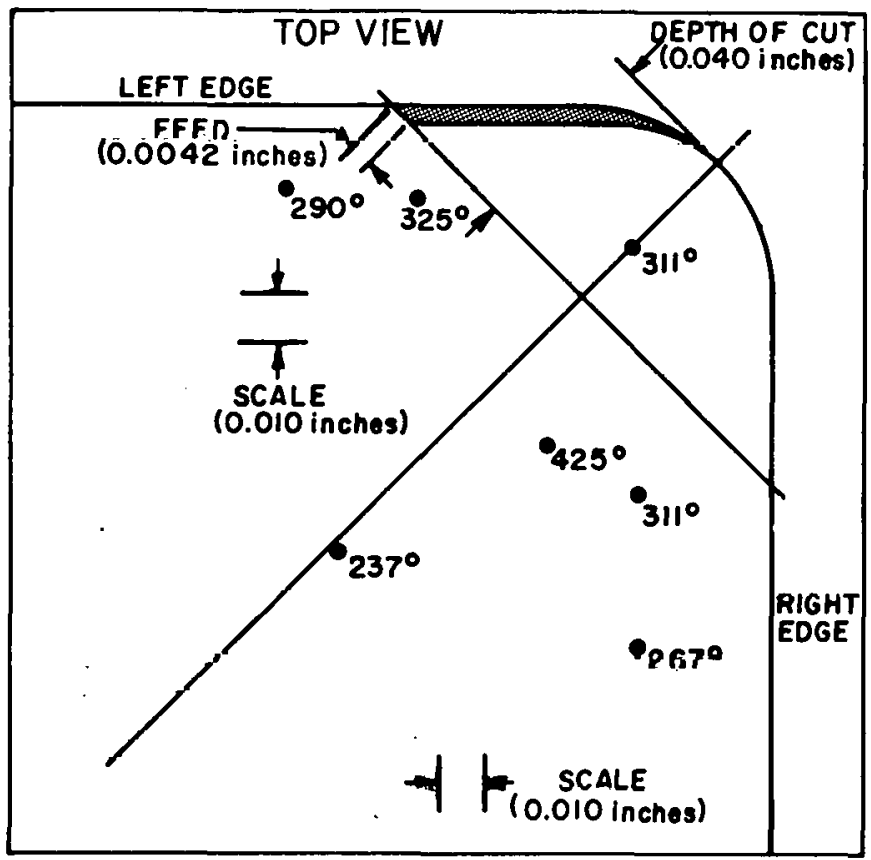

FIǴỦE $1 \overline{5}$. Surface Temperature Distribution.

FIGURE 16. Surface Temperature Distribution.

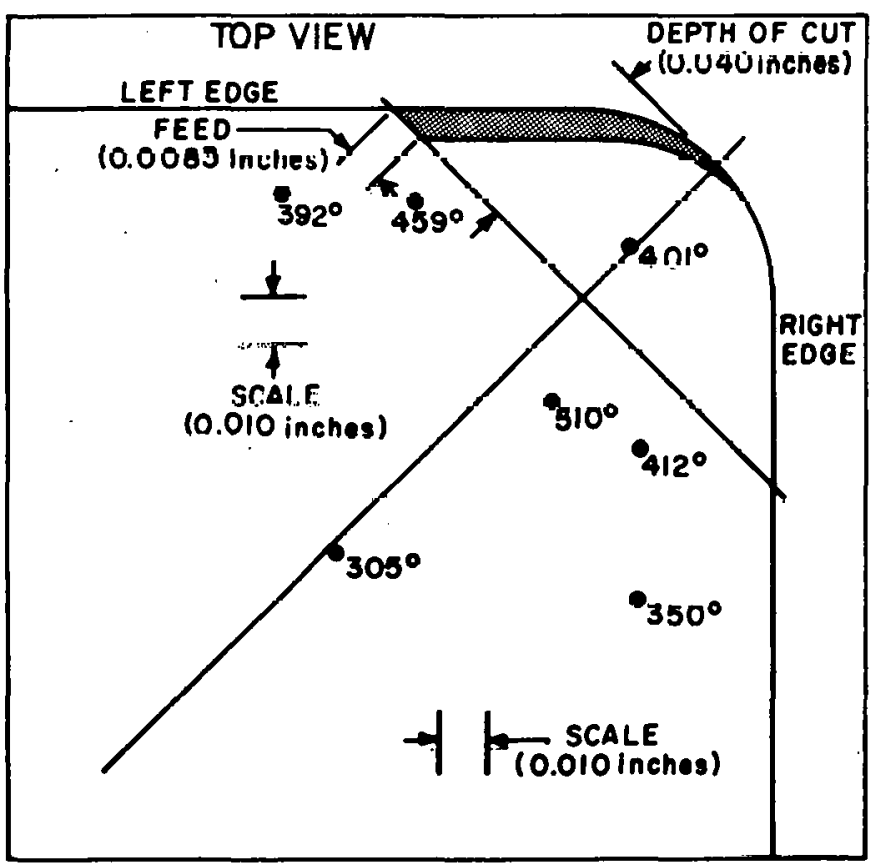

FIGURE 17. Surface Temperature Distribution.

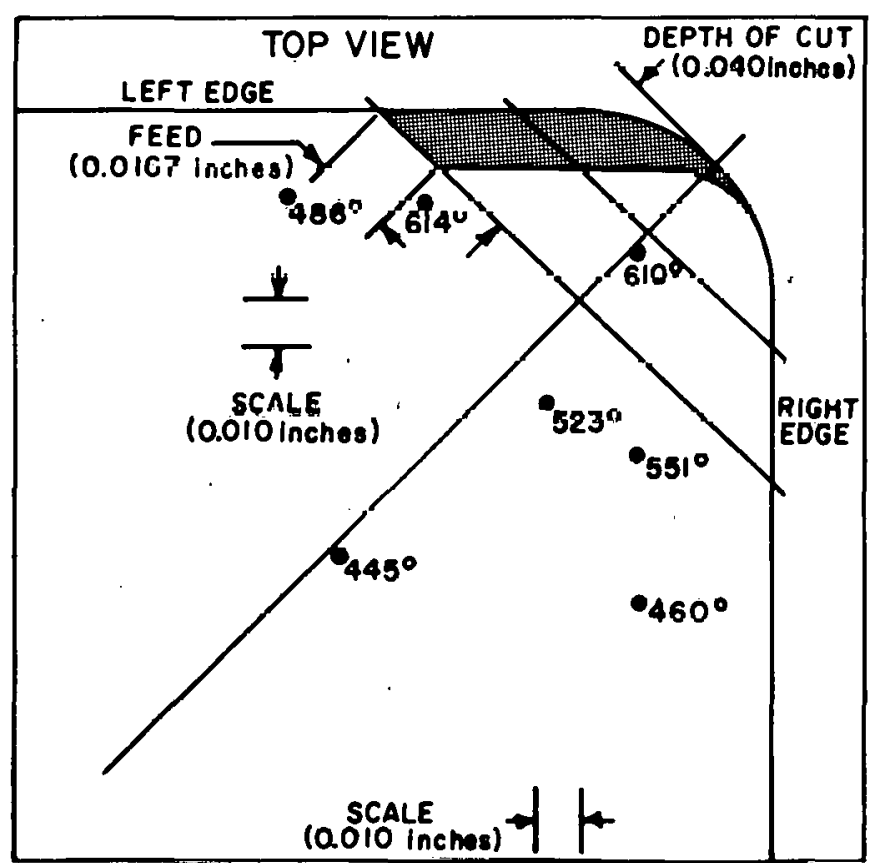




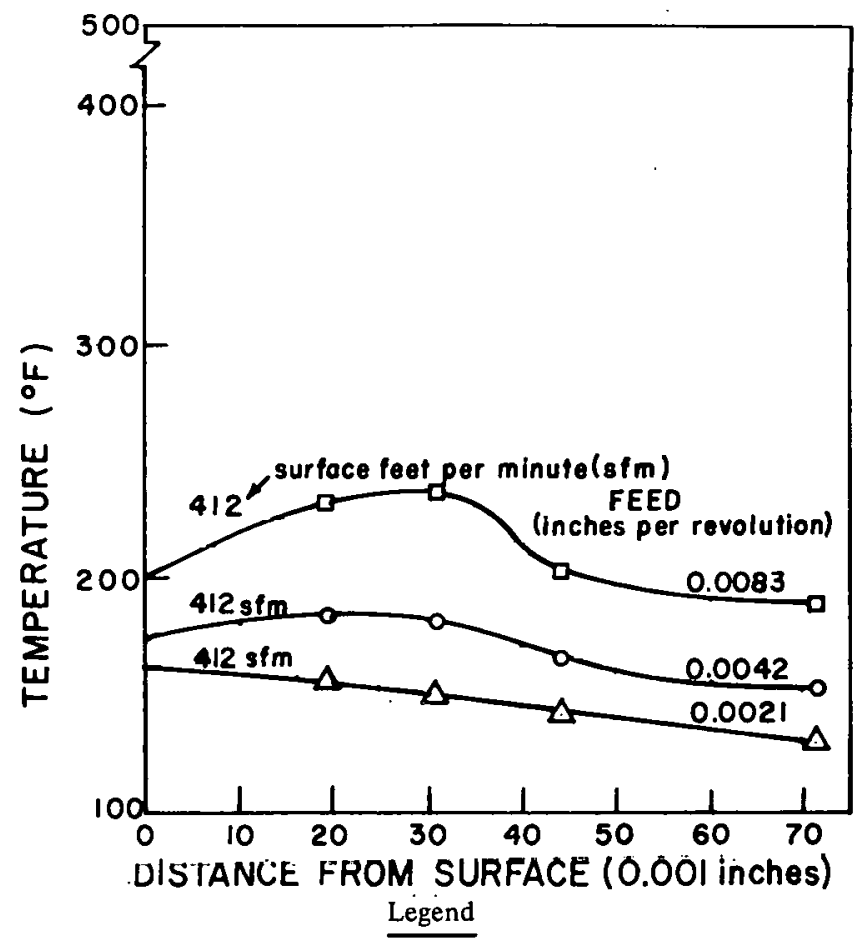

Position 1: Depth of Cut $=0.005$ inches.

FIGURE 18. Temperature versus Distance from Surface.

FIGURE 20. Temperature versus Distance from Surface.

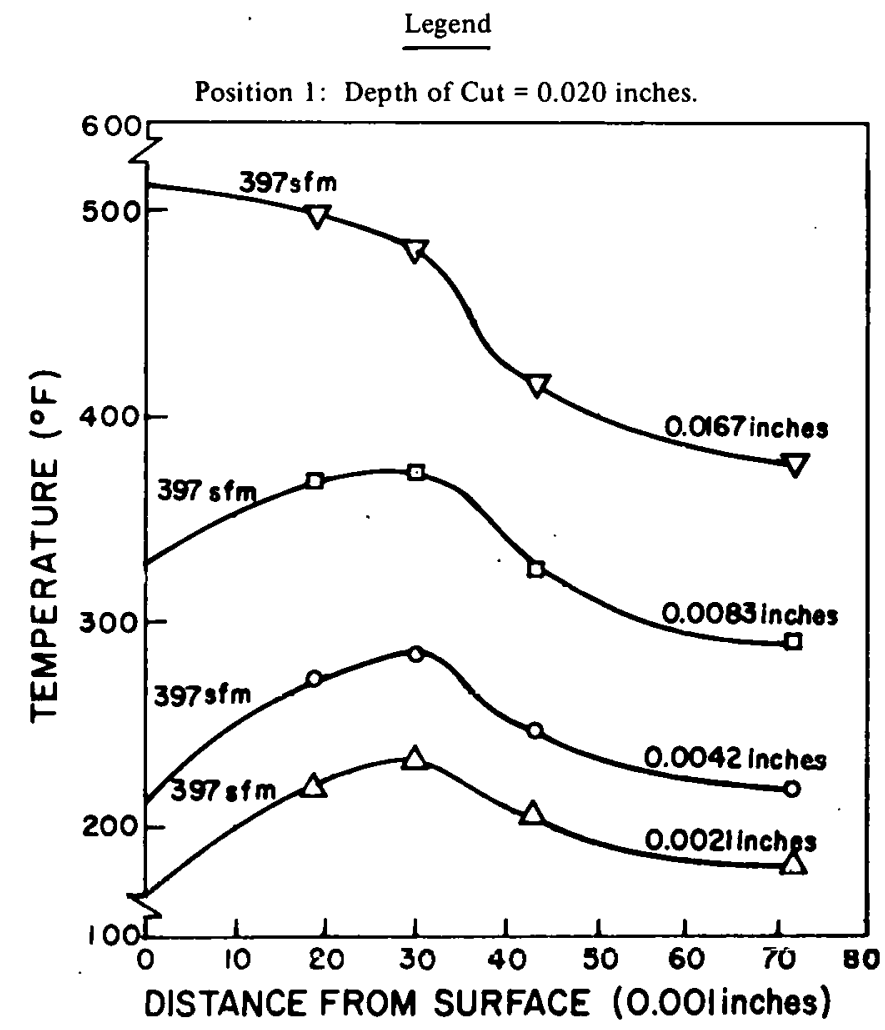

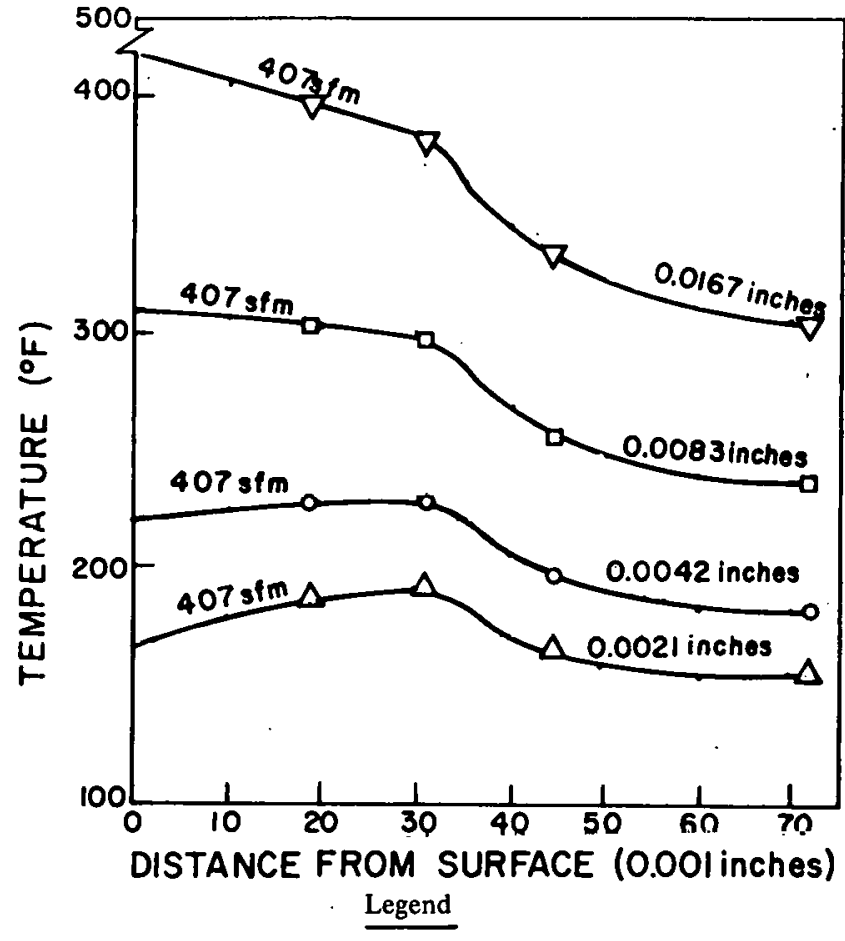

Position 1: Depth of Cut $=0.010$ inches

FIGURE 19. Temperature versus Distance from Surface.

FIGURE 21. Temperature versus Distance from Surface.

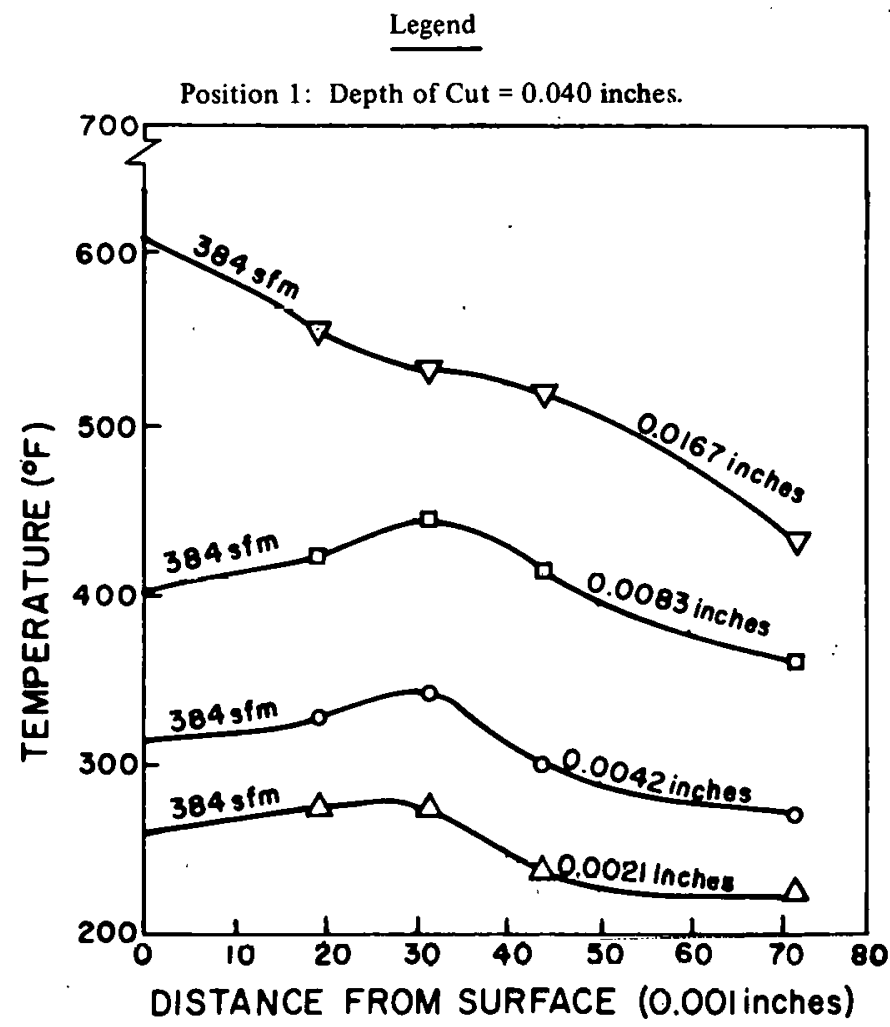




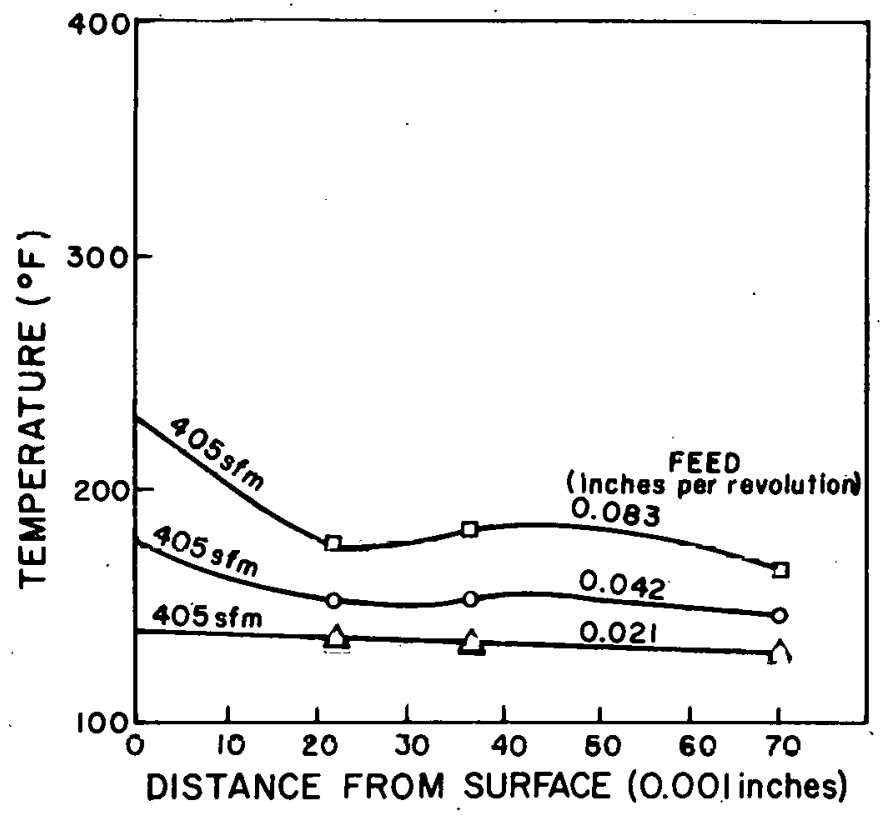

Legend

Position 3: Depth of Cut $=0.005$ inches.

FIGURF. 22. Temperature versus Distance from Surface.

FIGURE 24. Temperature versus Distance from Surface.

$$
\text { Legend }
$$

Position 3: Depth of Cut $=0.020$ inches.

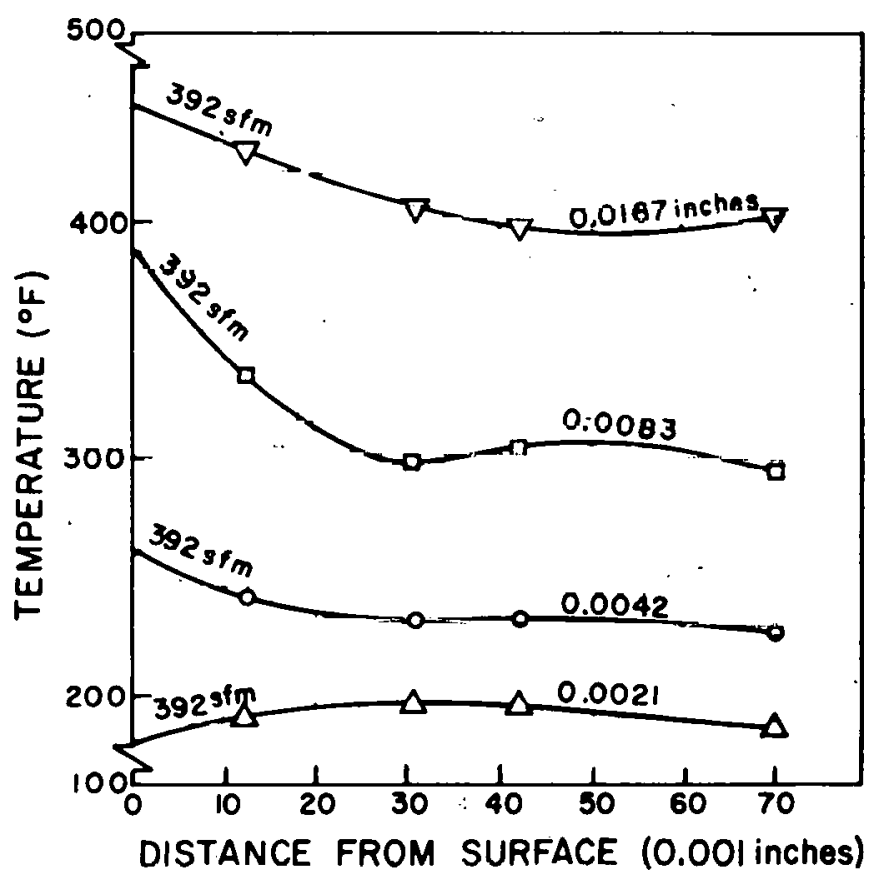

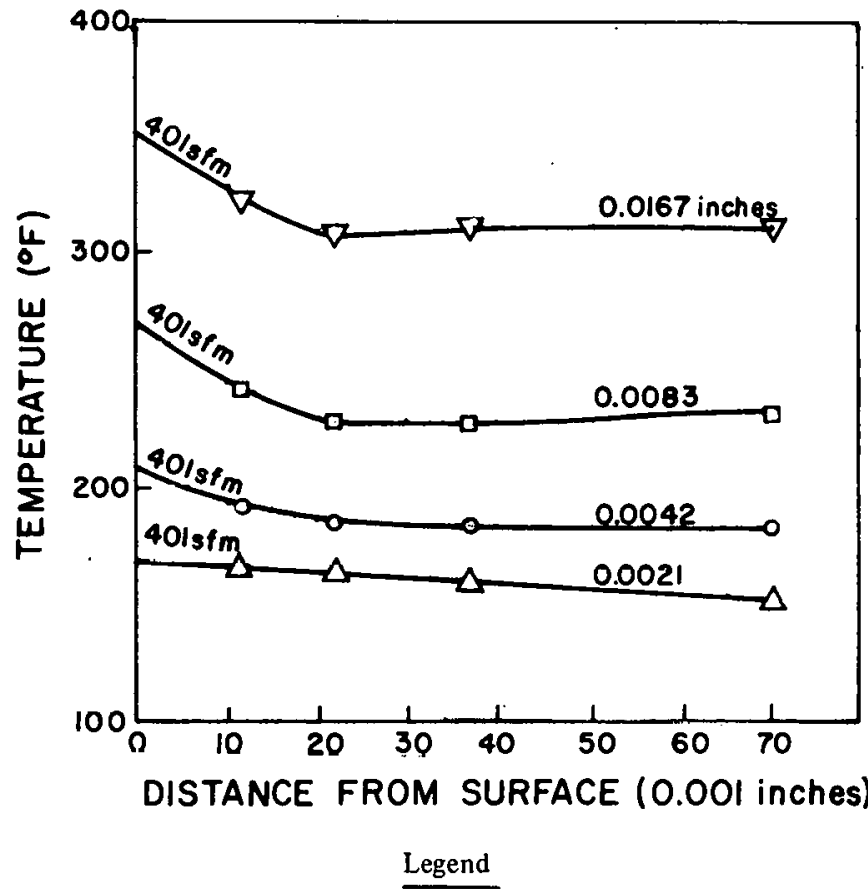

Position 3: Depth of Cut $=0.010$ inches.

FIGURE 23. Temperature versus Distance from Surface.

FIGURE 25. Temperature versus Distance from Surface.

\section{Legend}

Position 3: Depth of $\mathrm{Cut}=0.040$ inches.

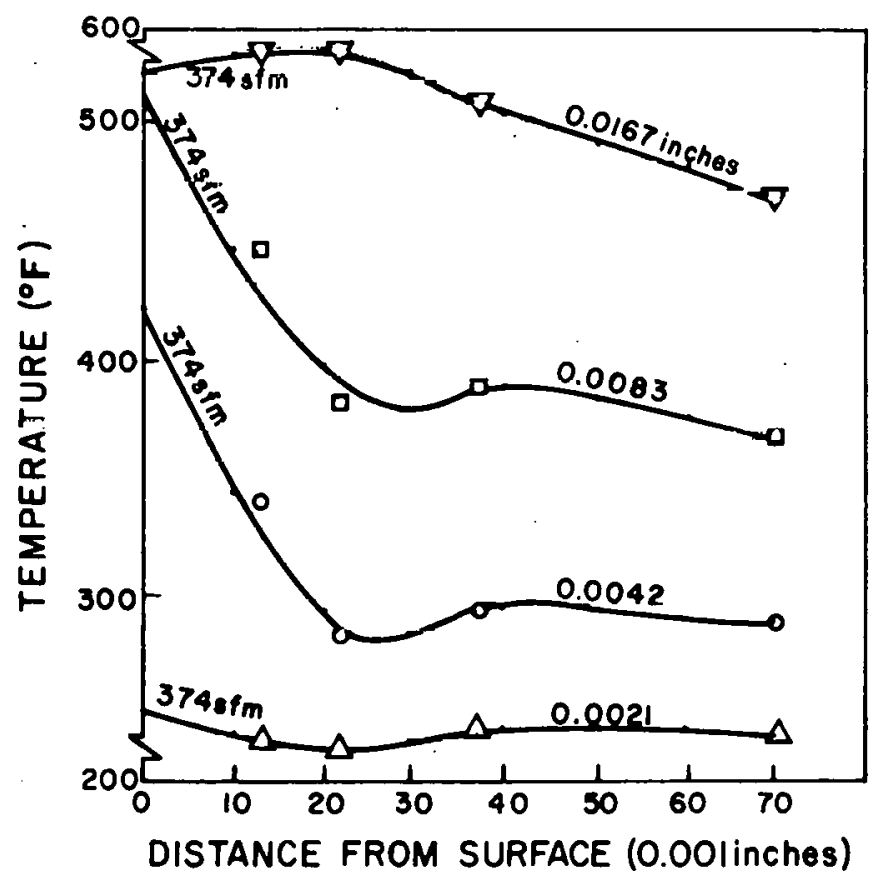


RFP-1409

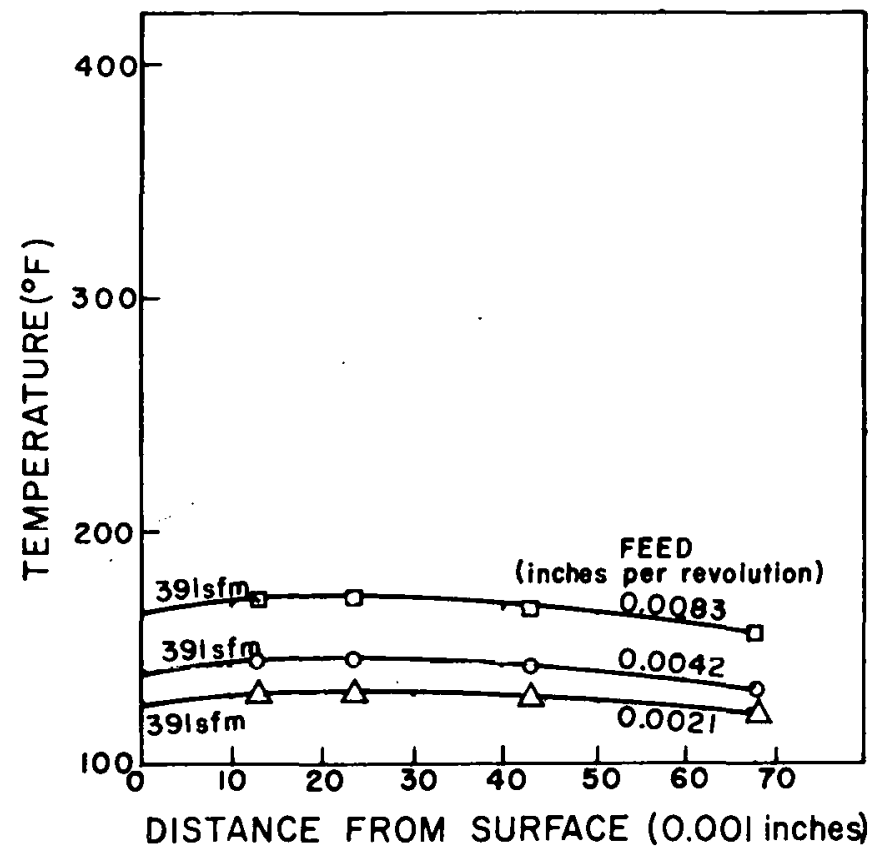

Pusition 4: Depth of Cut $=0.005$ inches.

FIGURE 26. Temperature versus Distance from Surface.

FIGURE 28. Temperature versus Distance from Surface.

Legend

Position 4: Depth of Cut $=0.020$ inches.

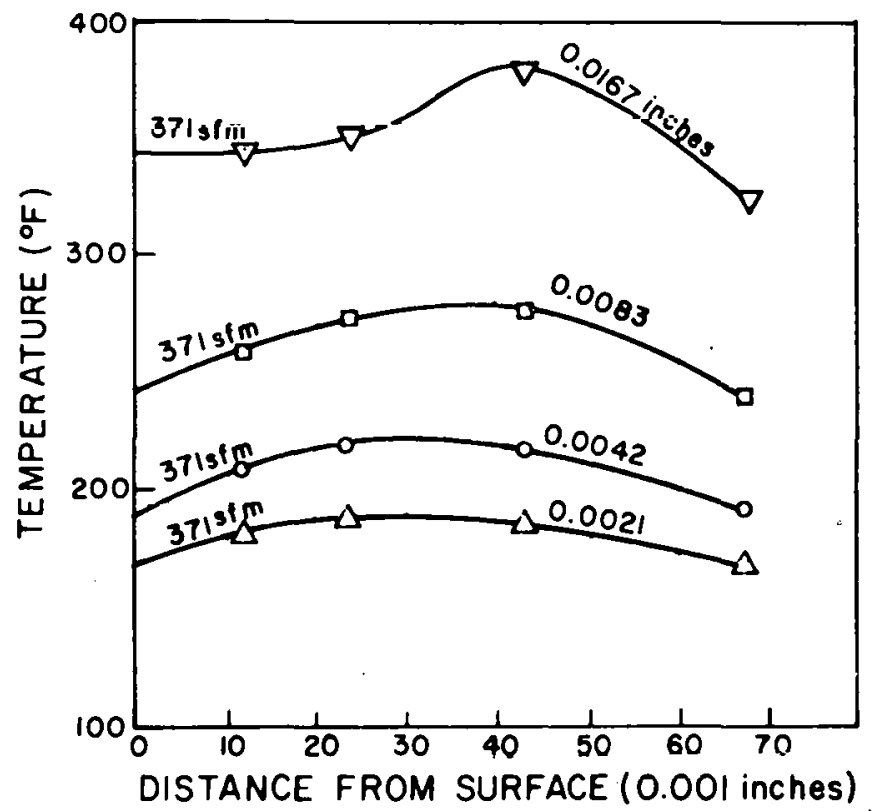

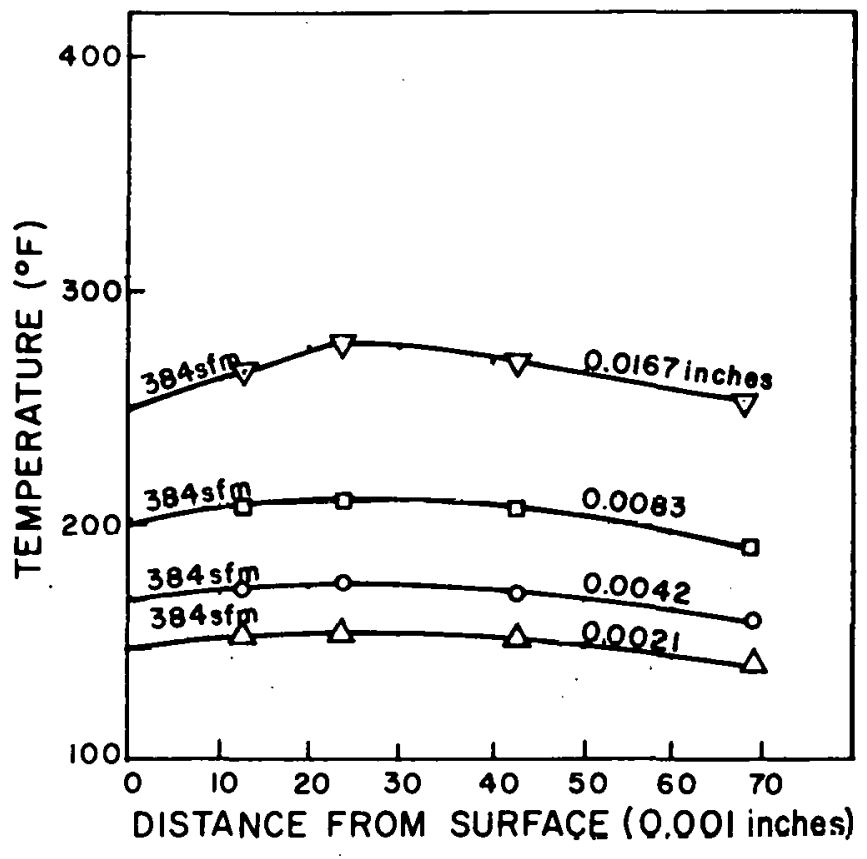

Legend

Position 4: Depth of Cut $=0.010$ inches.

FIGURE 27. Temperature versus Distance from Surface.

FIGURE 29. Temperature versus Distance from Surface.

Legend

Position 4: Depth of Cut $=0.040$ inches.

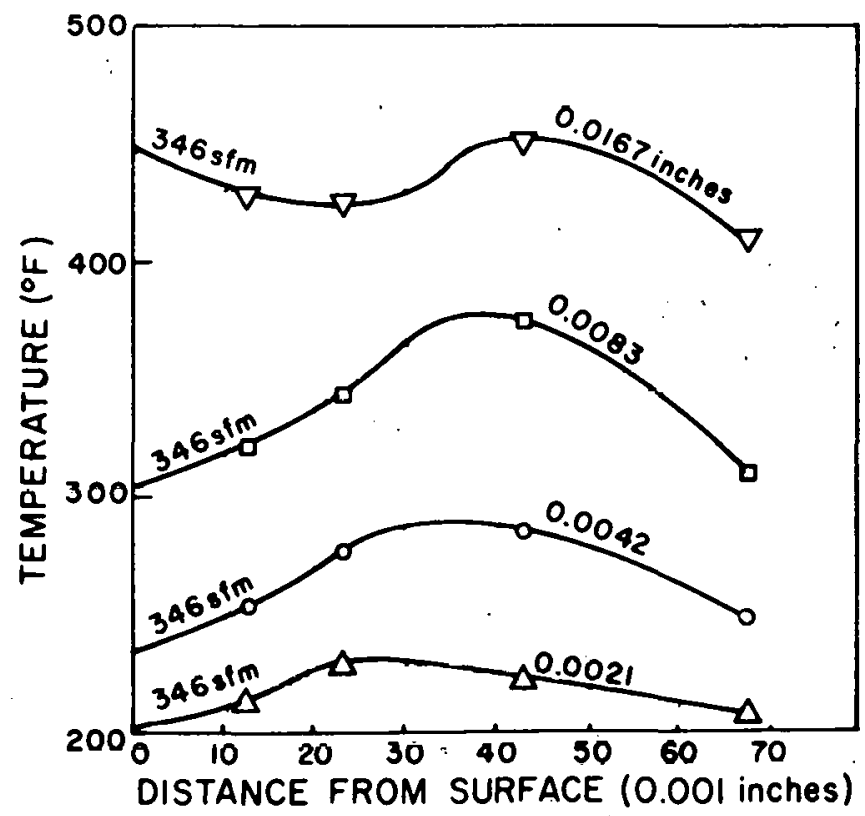




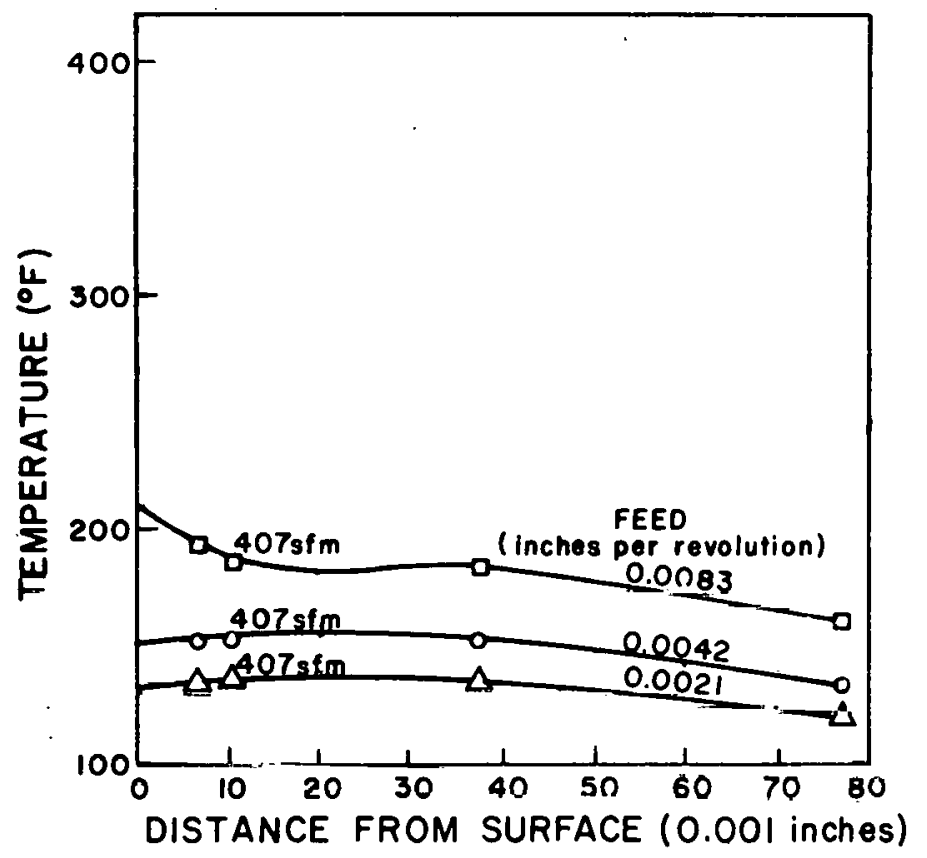

Legend

Position 5: Depth of Cut $=0.005$ inches.

FIGURE 30. Temperature versus Distance from Surface.

FIGURE 32. Temperature versus Distance from Surface.

Legend

Position 5: Depth of ( int $=0.020$ inches.

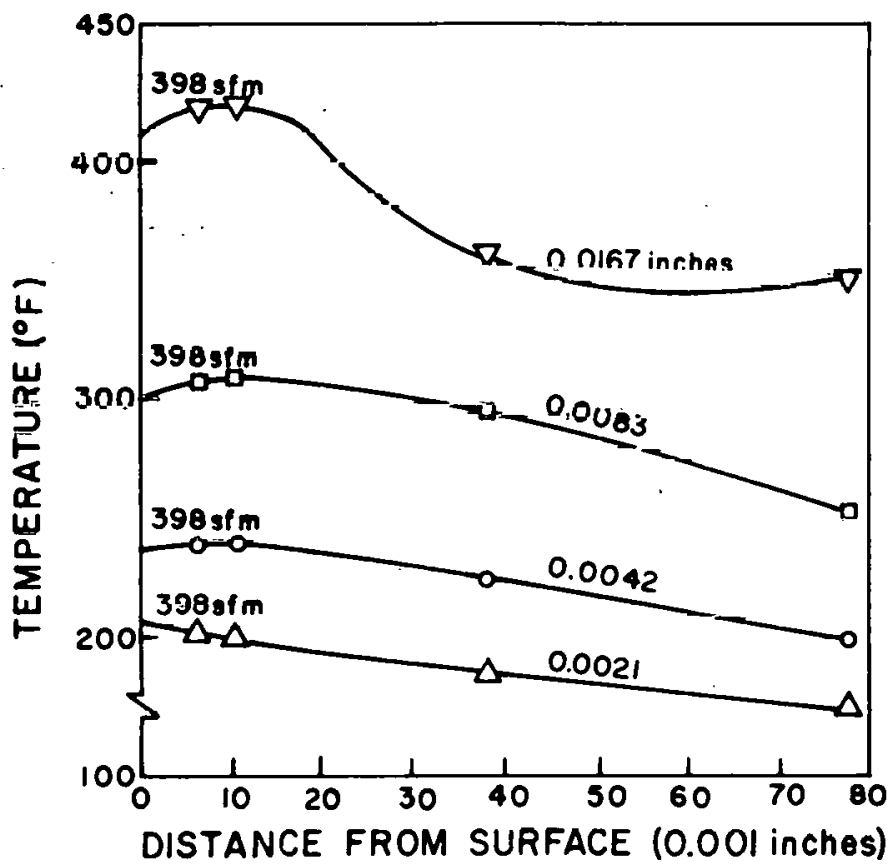

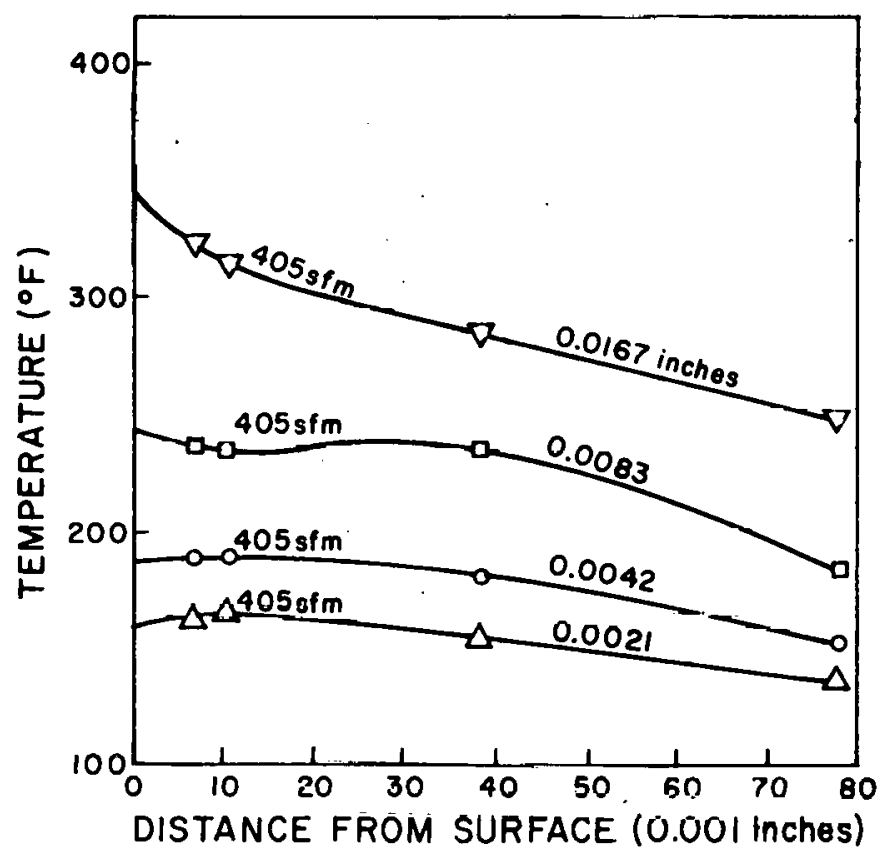

I. egend

Position 5: Depth of Cut $=0.010$ inches

FIGURE 31. Temperature versus Distance from Surface.

FIGURE 33. I emperature ver sus Dislarice from Surfaoo.

Legend

Position 5: Depth of Cut $=0.040$ inches

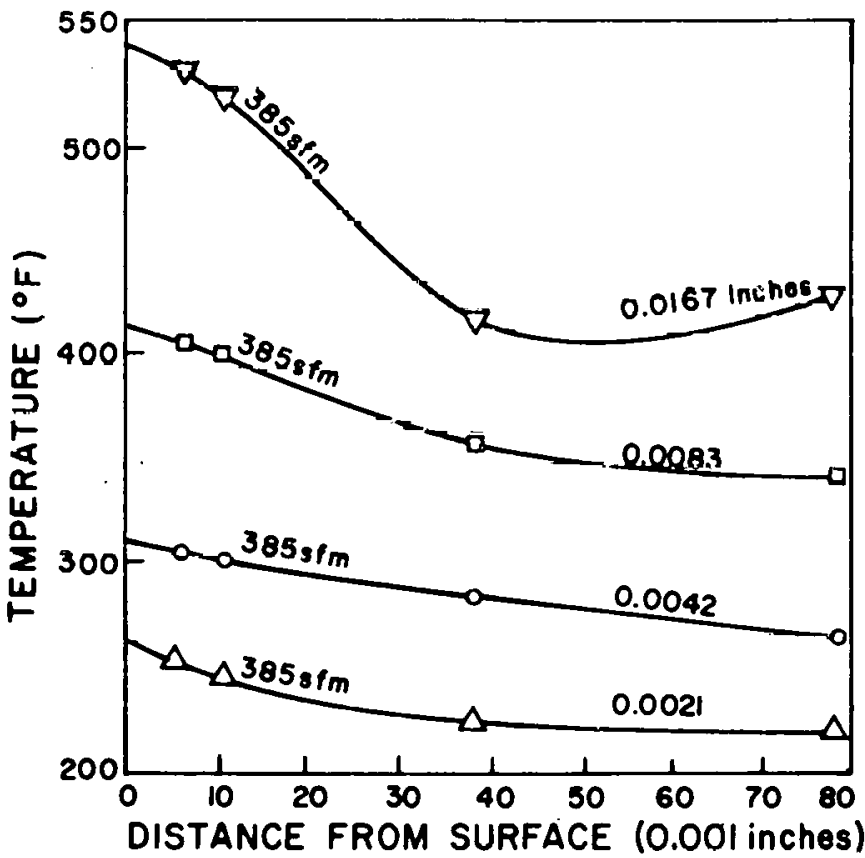




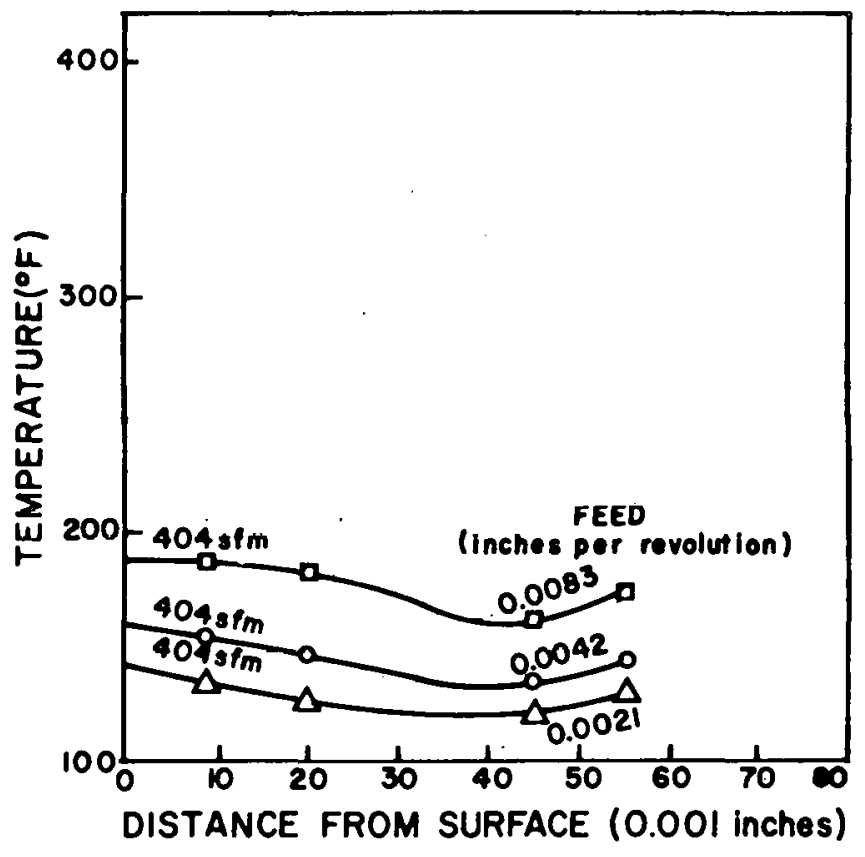

\section{Legend}

Position 6: Depth of Cut $=0.005$ inches.

FIGURE 34. Temperature versus Distance from Surface.

FIGURE 36. Temperature versus Distance from Surface.

Legend

Position 6: Depth of Cut $=0.020$ inches.

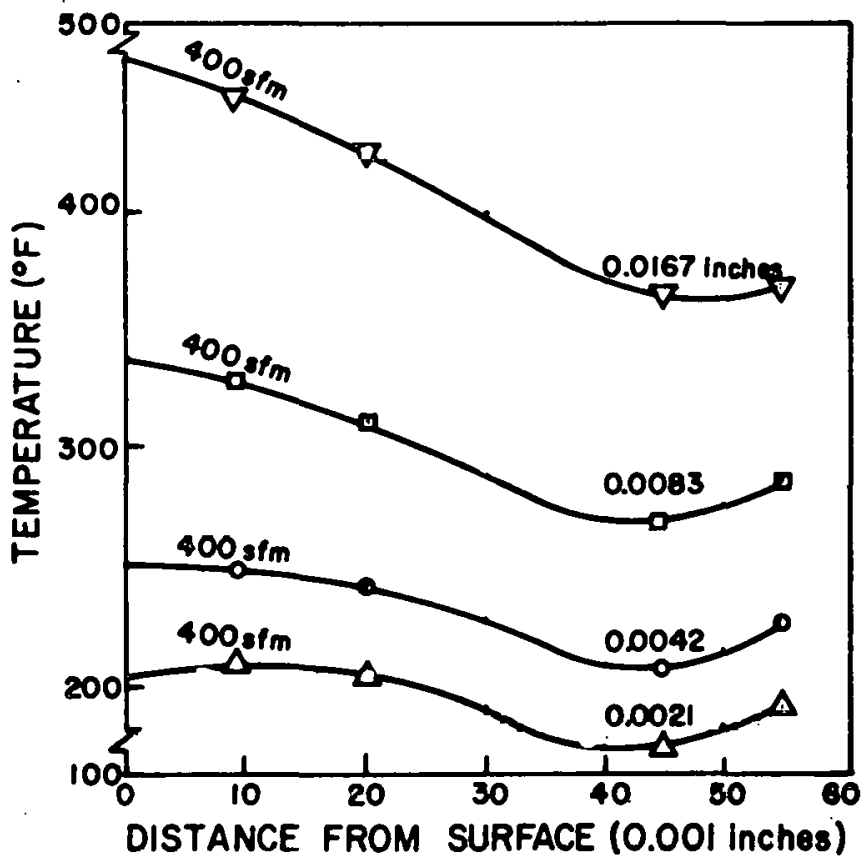

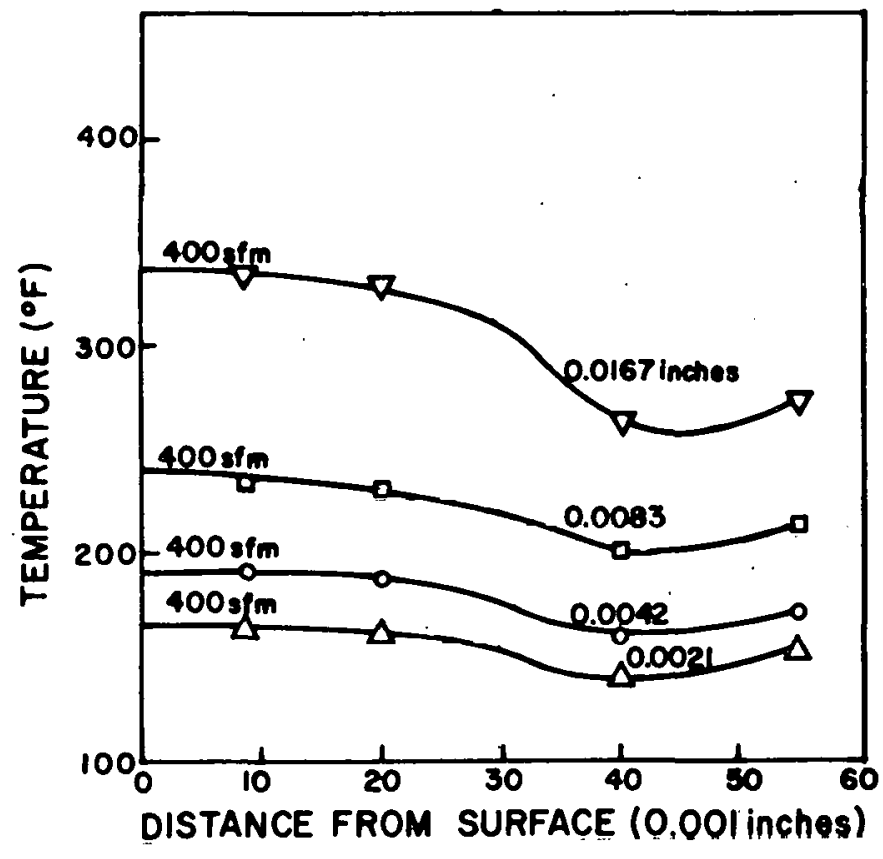

Legend

Position 6: Depth of Cut $=0.010$ inches.

FIGURE 35. Temperature versus Distance from Surface.

FIGURE 37. Temperature versus Distance from Surface.

Legend

Position 6: Depth of Cut $=0.040$ inches.

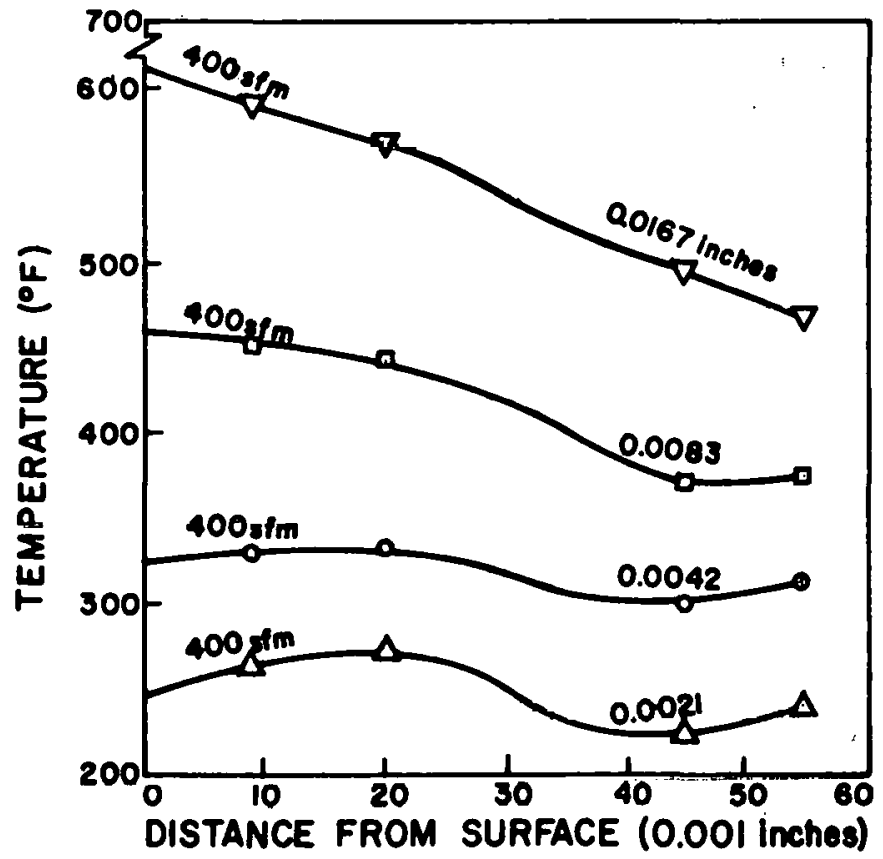




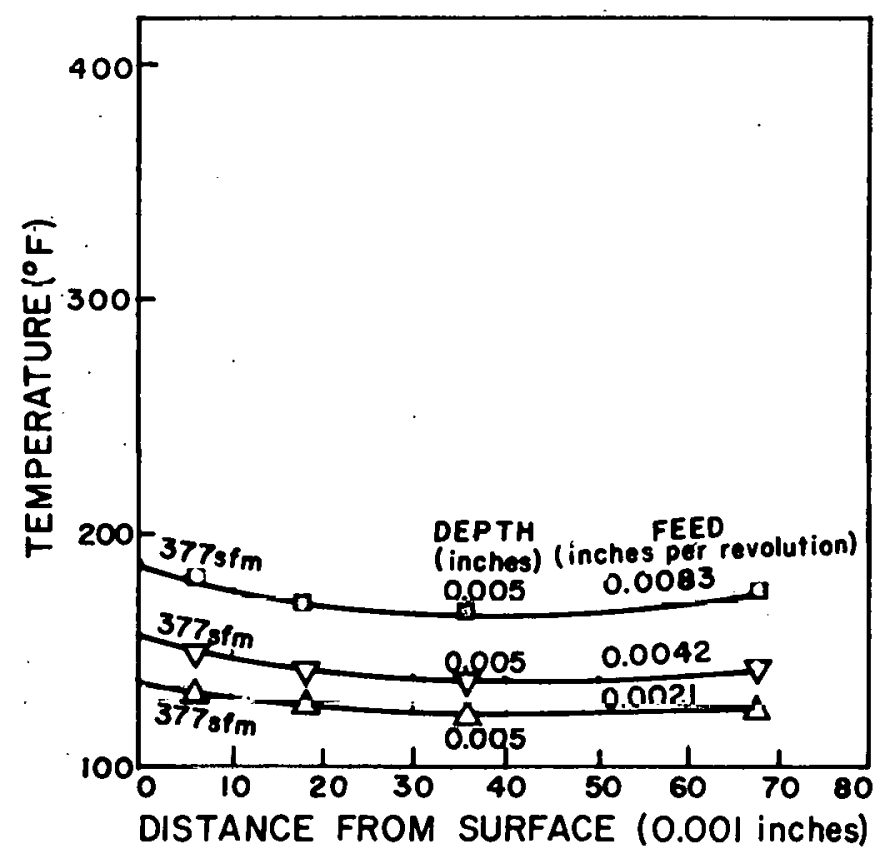

Legend

Position 7: Depth of Cut $=0.005$ inches.

FIGURE 38. Temperature versus Distance from Surface.

FIGURE 40. Temperature versus Distance from Surface.

\section{Legend}

Pocition 7: Depth of Cut $=0.020$ inches

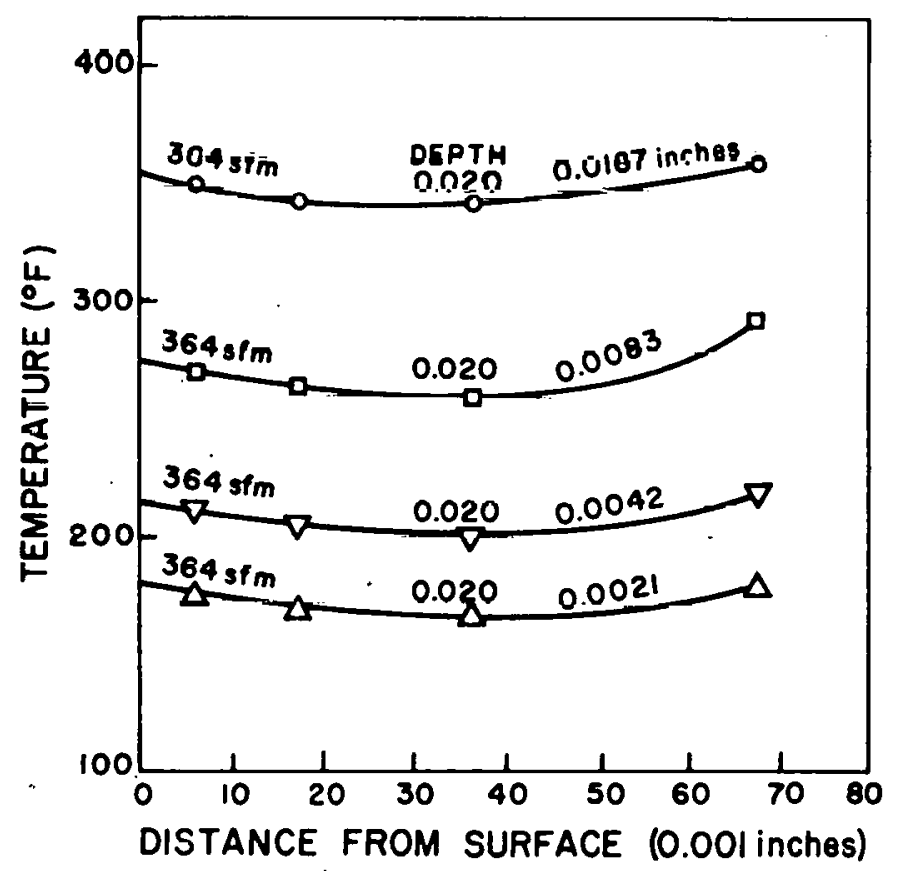

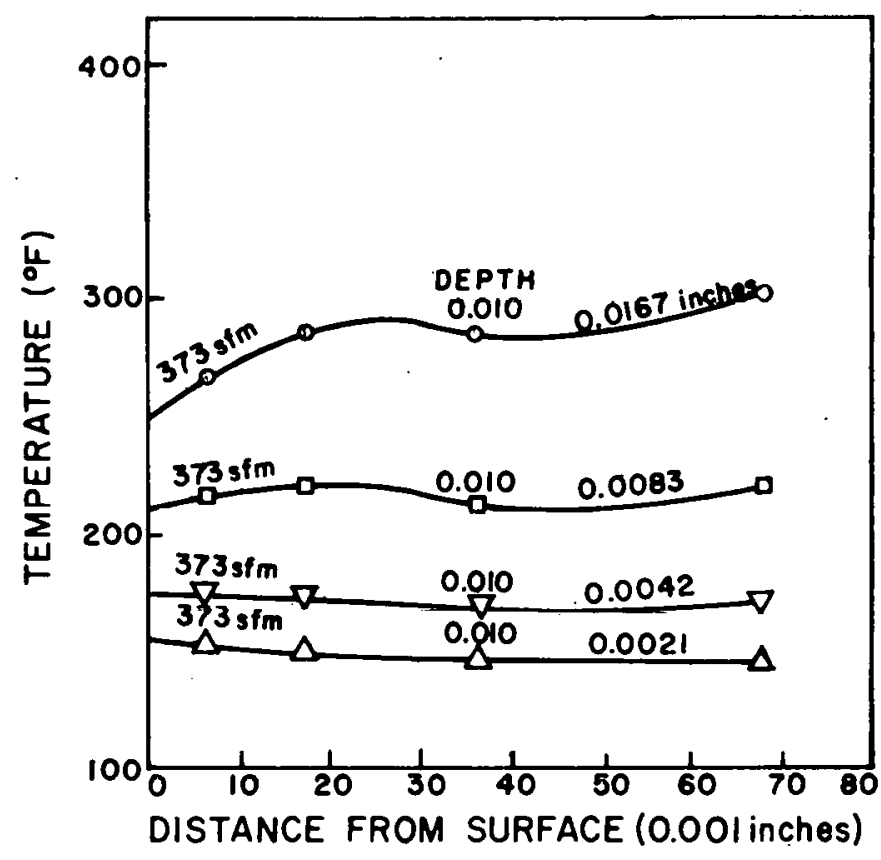

Legend

Position 7: Depth of Cut $=0.010$ inches.

FIGURE 39. Temperature versus Distance from Surface.

FIGUURE 41. Temperature versus Distance from Surface.

Legend

Position 7: Depth of Cut $=0.040$ inches.

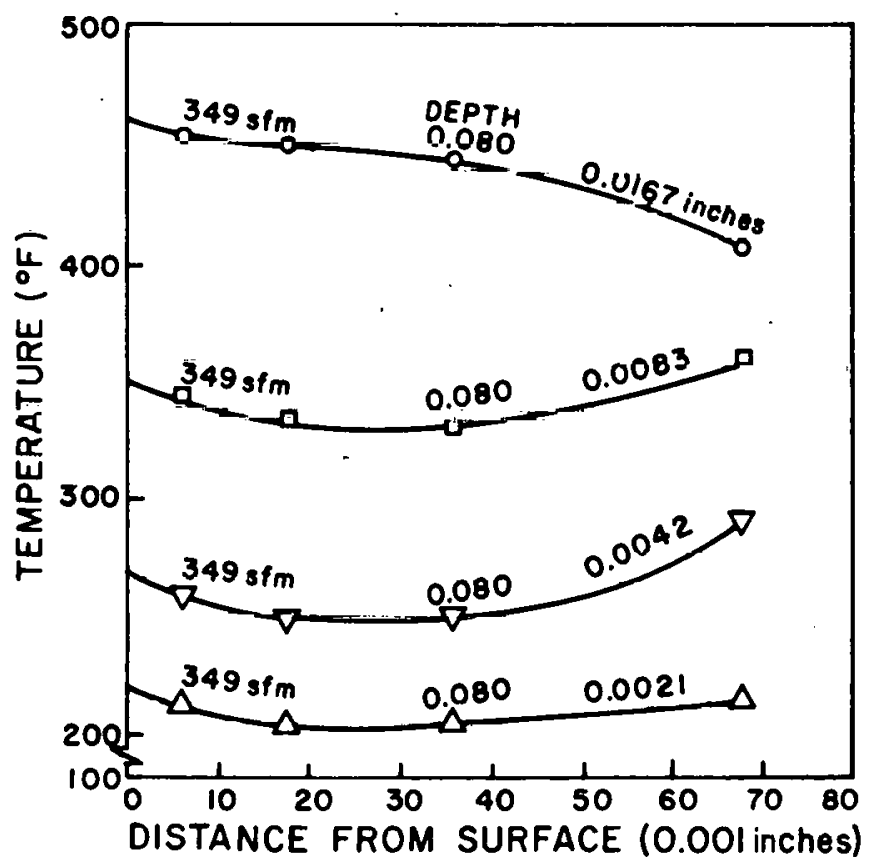




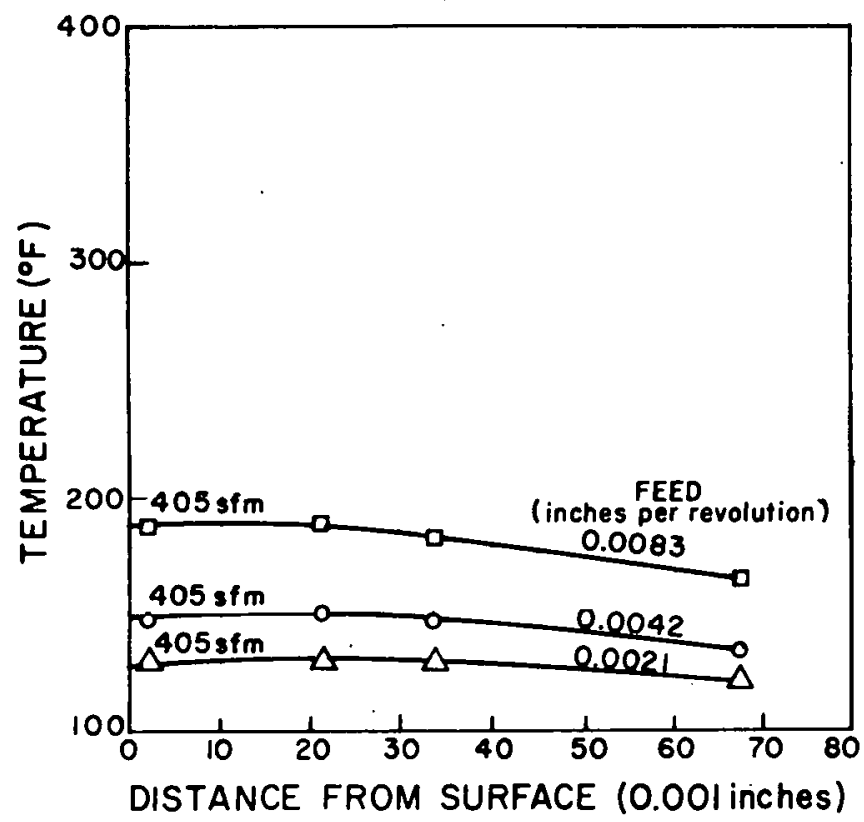

Legend.

Position 8: Depth of Cut $=0.005$ inches.

FIGURE 42. Temperature versus Distance from Surface.

FIGURE 44. Temperature versus Distance from Surface.

\section{Legend}

Position 8: Depth of Cut $=0.020$ inches.

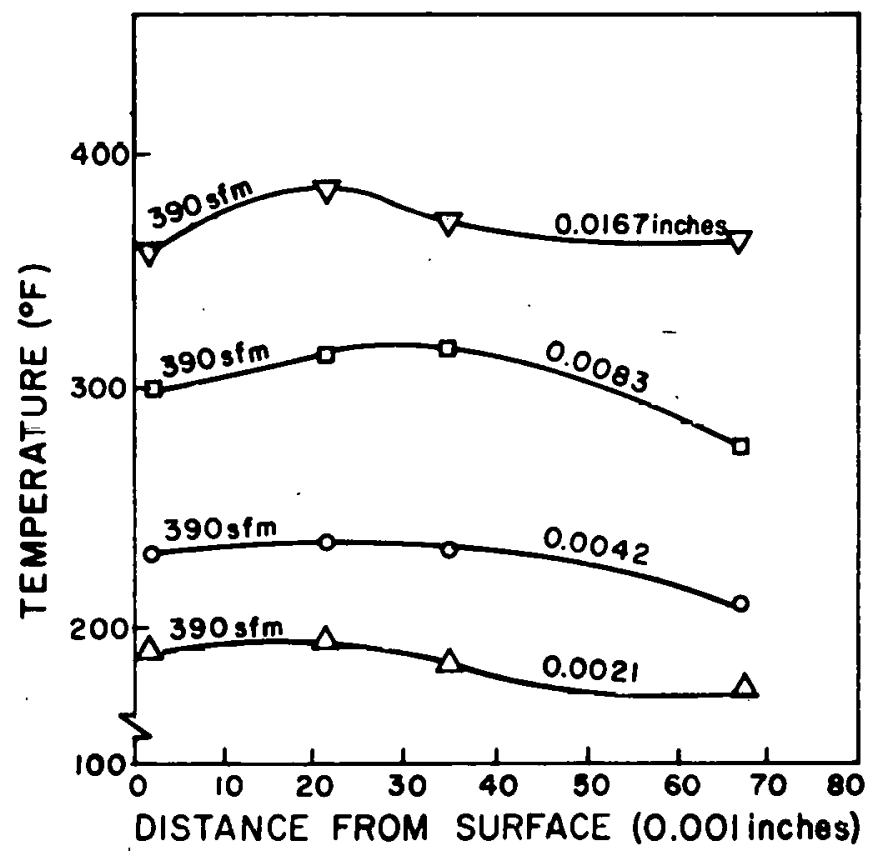

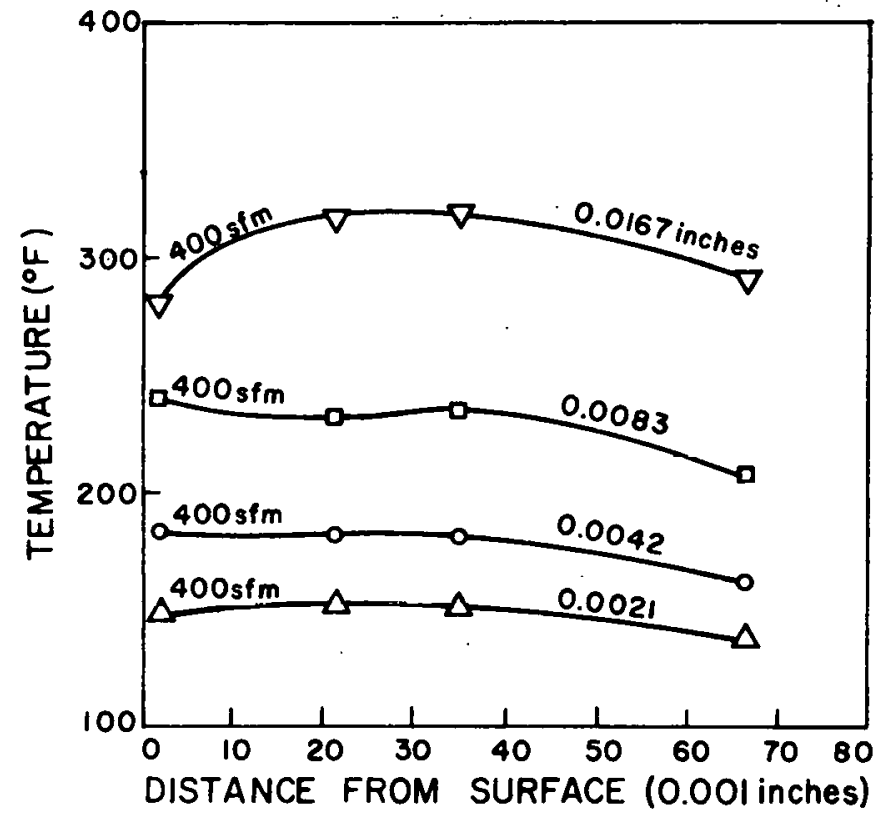

Legend

Position 8: Depth of Cut $=0.010$ inches.

FIGURE 43. Temperature versus Distance from Surface.

FIGURE 45. Temperature versus Distance from Surface.

\section{Legend}

Position 8: Depth of Cut $=0.040$ inches.

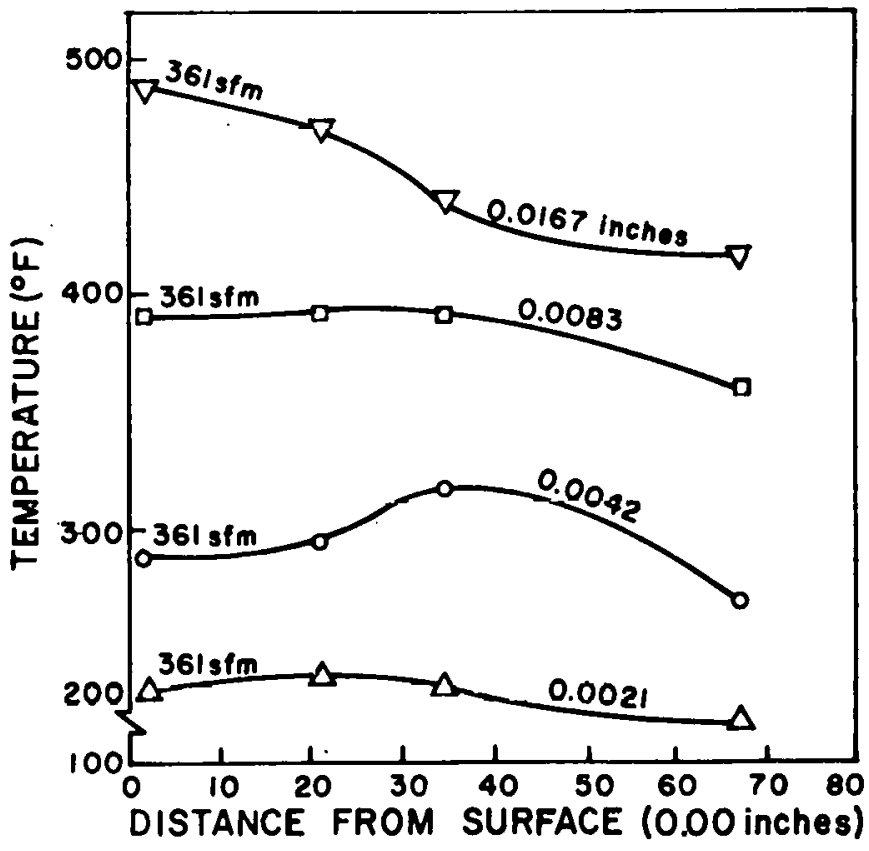

